\title{
Pescadoras capturam peixes e liberdade? Narrativa visual de uma experiência etnográfica na Lagoa Mirim
}

\author{
FISHERWOMEN CATCH FISHES AND FREEDOM? VISUAL NARRATIVE OF AN \\ ETHNOGRAPHIC EXPERIENCE WITH A FISHERWOMAN EMBARKED ON MIRIM \\ LAGOON \\ ¿PESACADORAS CAPTURAN PECES Y LIBERTAD? NARRATIVA VISUAL DE UMA \\ EXPERIENCIA ETNOGRÁFICA EM LA LAGUNA MIRIM
}

\author{
Liza Bilhalva Martins \\ Gianpaolo Adomilli*1 \\ lizabms@gmail.com \\ Recibido: 04/4/2020 Aceptado: 02/9/2020
}

Este ensaio parte das observações e participações do trabalho de campo no âmbito da pesquisa desenvolvida com pescadoras embarcadas em contextos lagunares no sul do Brasil e tem como objetivo, apresentar esse universo através das imagens e da escrita etnográfica. A proposta é conduzir a/o leitora/or a navegar com a pescadora Márcia durante um dia de seu labor diário na Lagoa Mirim.

Experienciar com as pescadoras os significados e sentidos de ser uma mulher que atua na etapa da captura do pescado constitui um dos principais desafios da pesquisa, no esforço de compreender, na prática, o viver e o saber-fazer para estar e se manter nessa atividade tida como majoritariamente masculina no imaginário social, cultural e político brasileiro.

Todas as imagens foram captadas pela autora no dia dezessete de setembro de $2019 \mathrm{em}$ uma jornada embarcada com a pescadora Márcia (Figura 2). Conforme nos mostra o mapa (Figura1) a partida se deu no Porto de Pindorama em Santa Vitória do Palmar com destino à localidade Pontal de Canoa (direção norte da lagoa Mirim).

\footnotetext{
$1 *$ Universidade Federal do Rio Grande - FURG.
} 


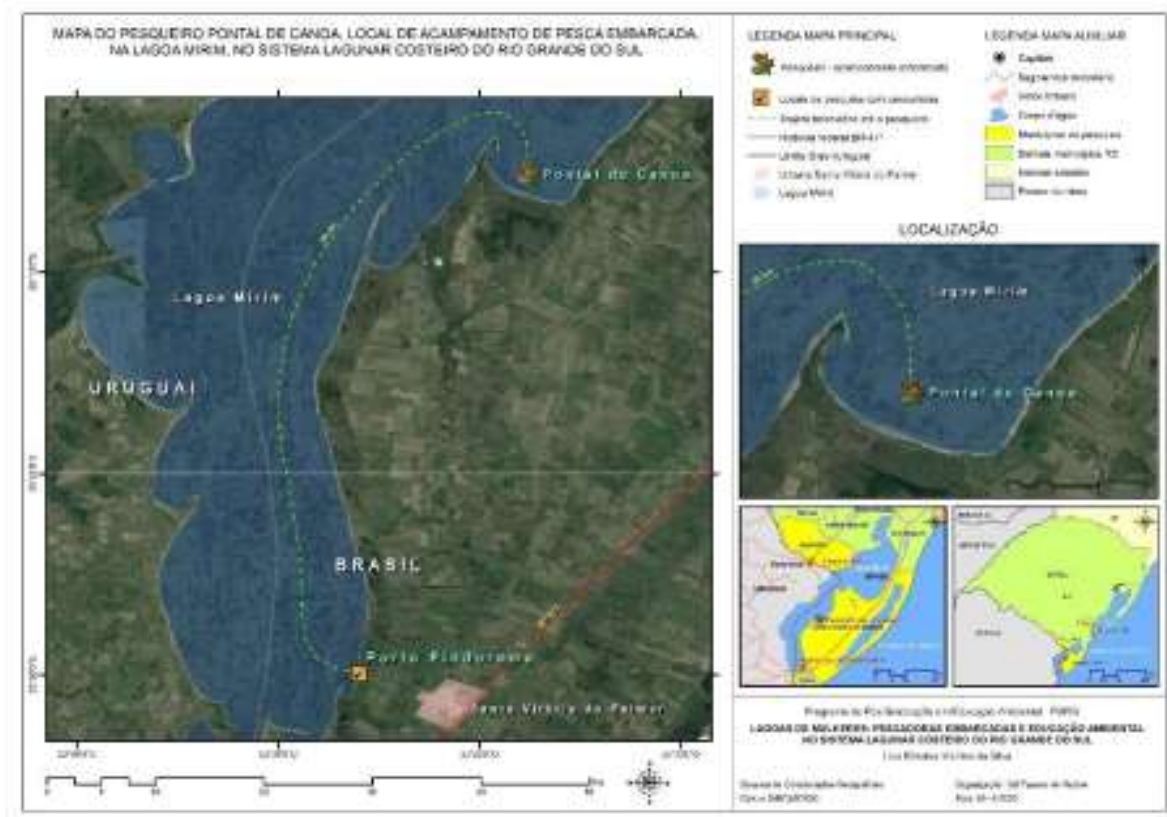

Figura 1 Mapa Lagoa Mirim - Localidade de partida Santa Vitória do Palmar (Porto de Pindorama) destino Pontal de Canoa

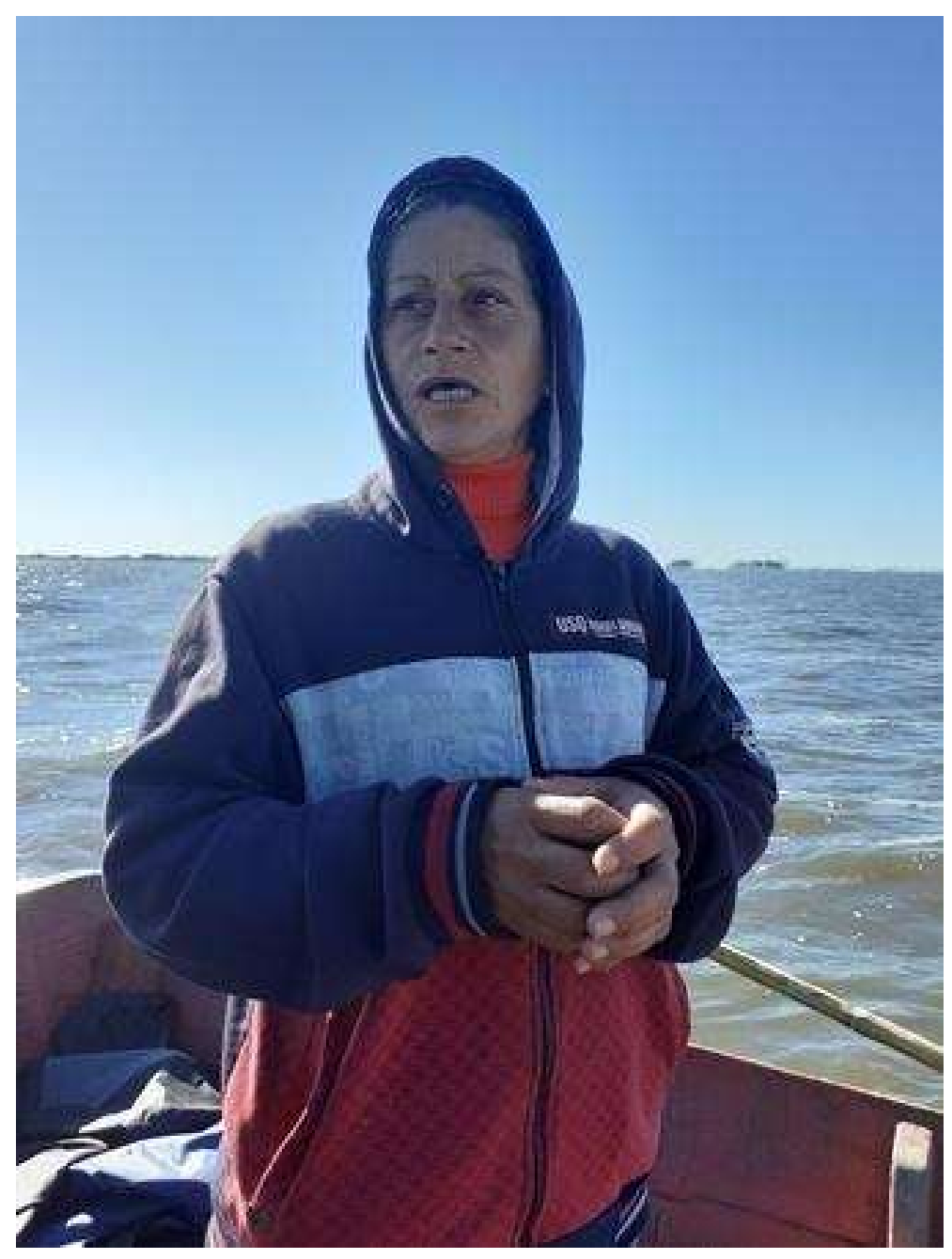


Figura 2 - Preparativos para a saída. Márcia orientando a pesquisadora sobre como seria a viagem.

Márcia tem 49 anos e pesca desde os 8 anos de idade, aprendeu com seu pai e sua mãe e foi casada com dois pescadores. Hoje é separada e de seus quatro filhos, três pescam. Márcia é uma pescadora muito experiente, desde 1985 pesca sozinha ou com os filhos de forma artesanal/profissional na embarcação de sua propriedade. É uma mulher forte, em vários sentidos. Na força corporal e nas decisões, demostra grande conhecimento sobre a arte de pescar conforme pude constatar durante a viagem e nas conversas ao longo da pesquisa.

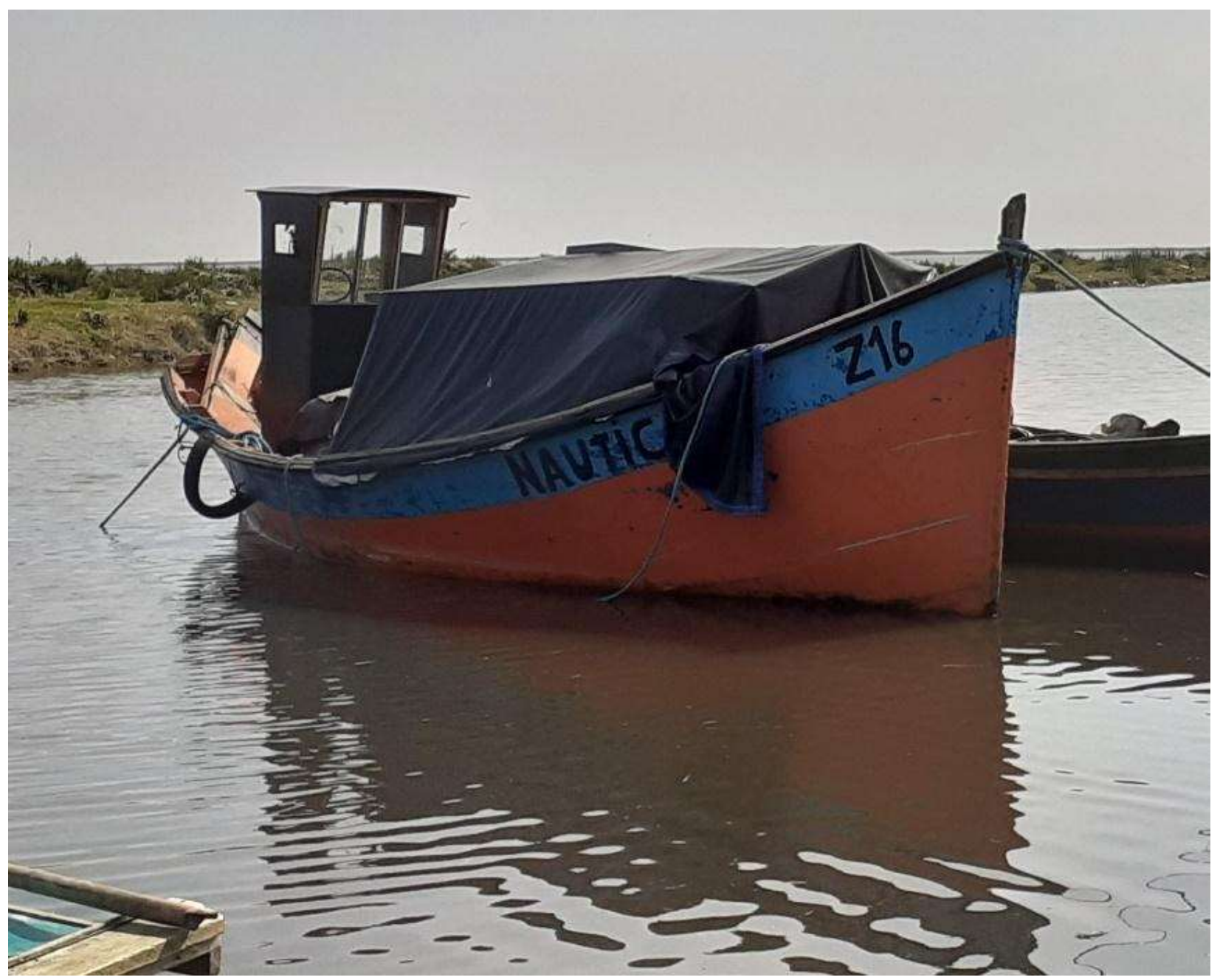

Figura 3 - Barco Náutico

Eram sete horas da manhã quando começamos a organizar os petrechos de pesca que levaríamos para o barco. Era um lindo dia de sol no final do inverno de 2019 no Porto de Pindorama em Santa Vitória do Palmar. Tudo parecia estar em ordem para embarcarmos no Náutico, barco de propriedade da pescadora Márcia e, para mim, na grande aventura antropológica que estava por vir.

Márcia ligou o motor e disse: o vento está Nordeste e o mar está proa. Vamos contra a maré. Está tudo sob controle. Partimos eu, a pescadora e o filho mais novo de Márcia (Figura 3). 


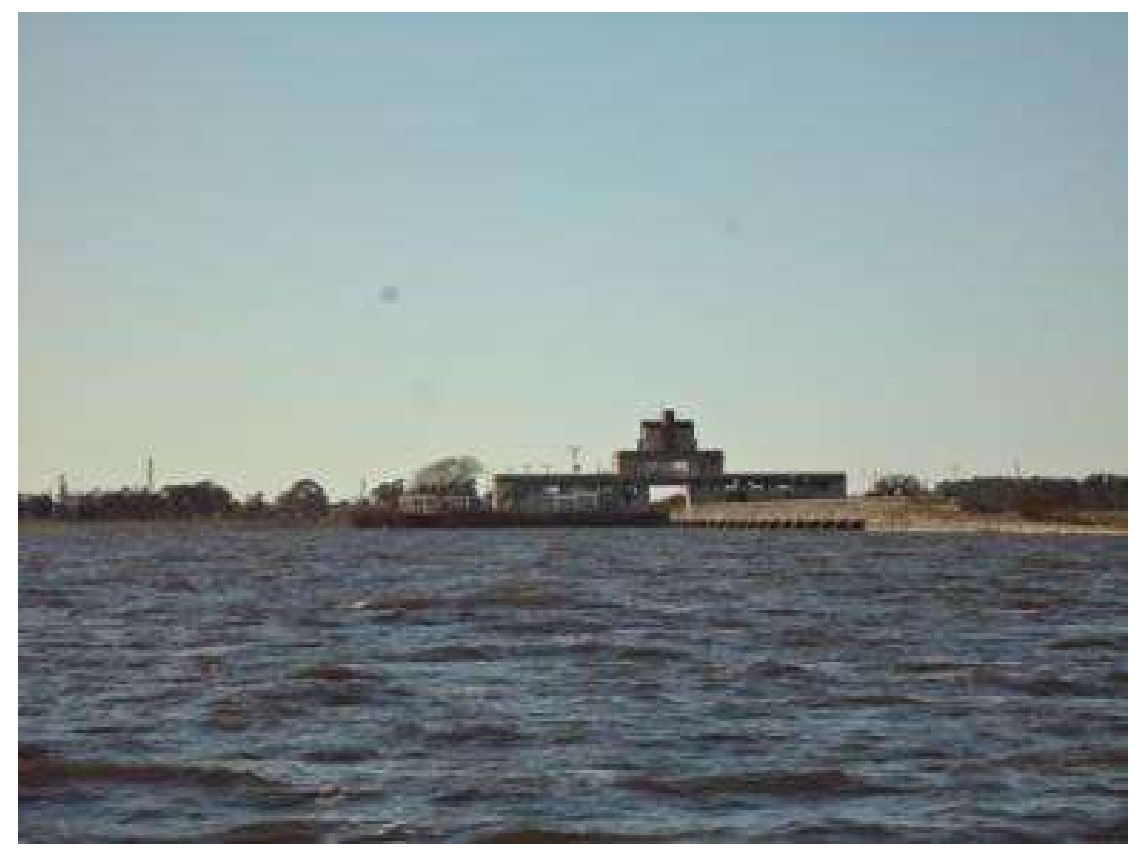

Figura 4 - Vista do porto de Pindorama, começa a viagem.

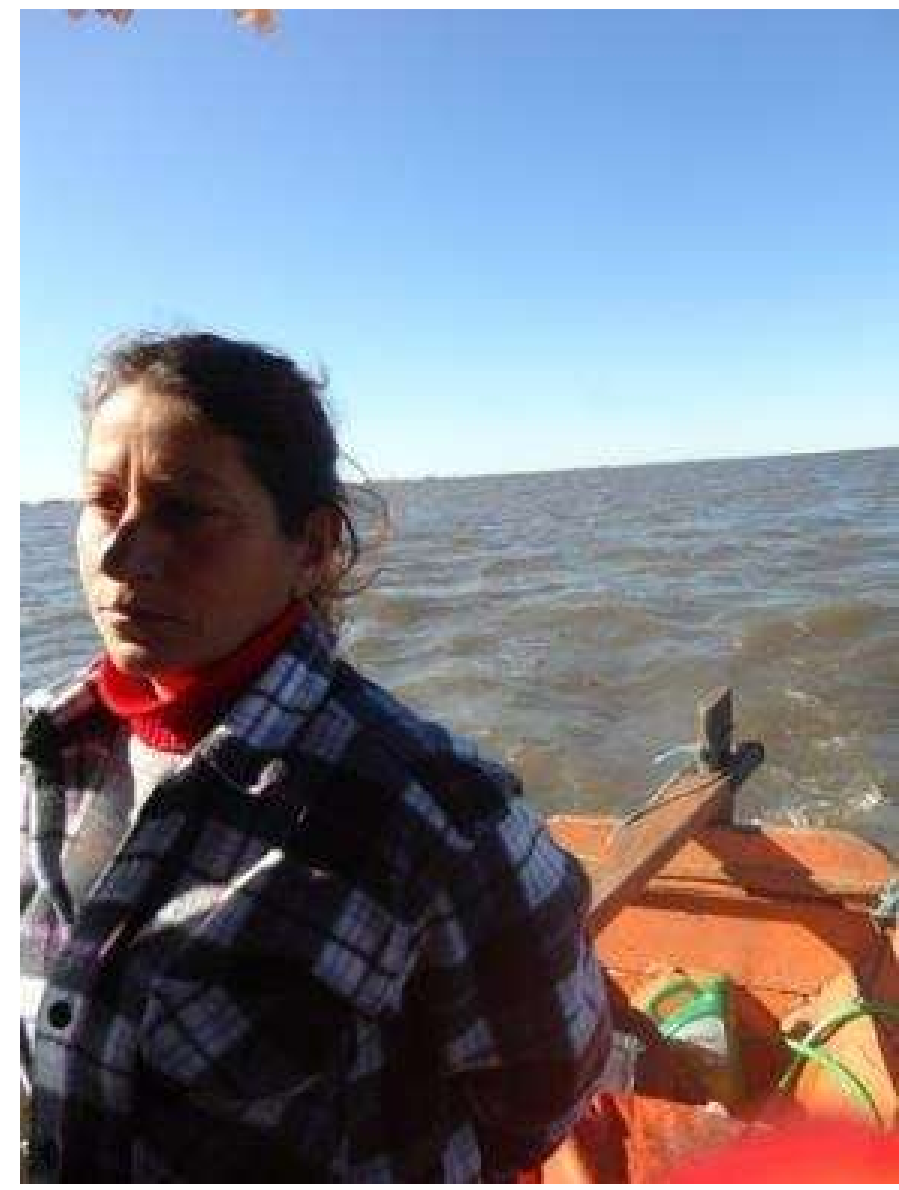

Figura 5 - Márcia guia o barco manejando o leme na polpa (parte de trás da embarcação) em direção ao local de pesca na Lagoa Mirim. 


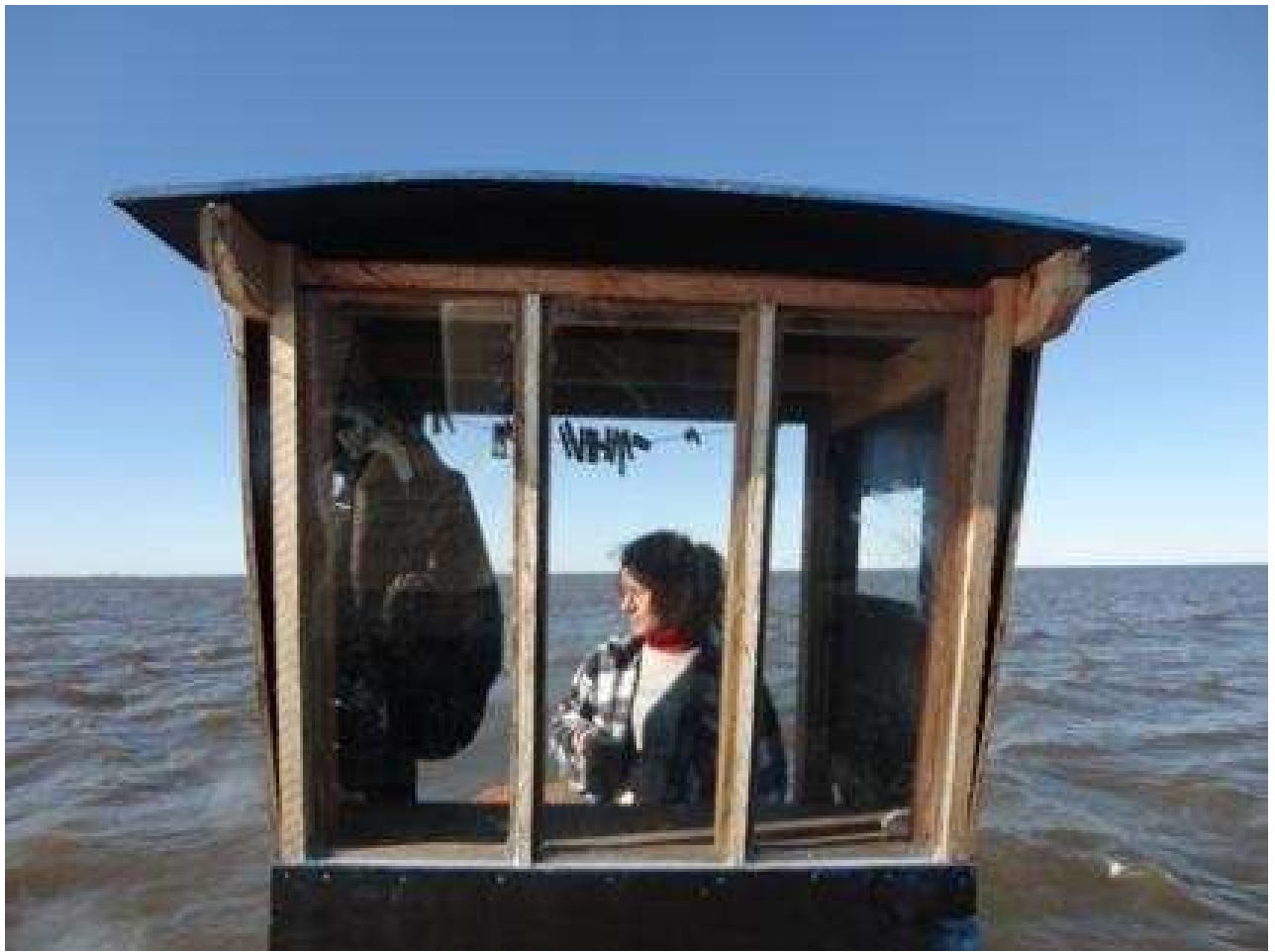

Figura 6 - - Olhar atento da Márcia na cabine da embarcação

Era a primeira vez que embarcava na Lagoa Mirim ao lado de uma pescadora. A experiência gerava em mim uma sensação ambígua: certa incerteza, medo e, ao mesmo tempo, empolgação com os novos horizontes que uma etnografia embarcada me possibilitaria. A ansiedade me tomava e acredito que o mesmo sentimento estava em Márcia por estar levando consigo uma pesquisadora curiosa, mas completamente neófita nas lides da pesca.

Quando partimos, observei como Márcia se comportava e fui imitando seus movimentos. Percebi que deveria deixar meu corpo se mover no mesmo ritmo do barco, não resistir ao balanço e, caso me sentisse enjoada, veria o que fazer. A literatura antropológica nos conta que conseguir superar o mal-estar é um desafio, uma prova de fogo.

Adomilli (2007) e Gerber (2015) nos dizem que essa situação faz parte da experiência de pescadores e pescadoras, bem como dos pesquisadores e pesquisadoras em trabalho de campo. Para novatos, a prova de aguentar o trabalho passa primeiramente por vencer o enjôo. Mas estava dando certo! Eu não estava enjoando. 


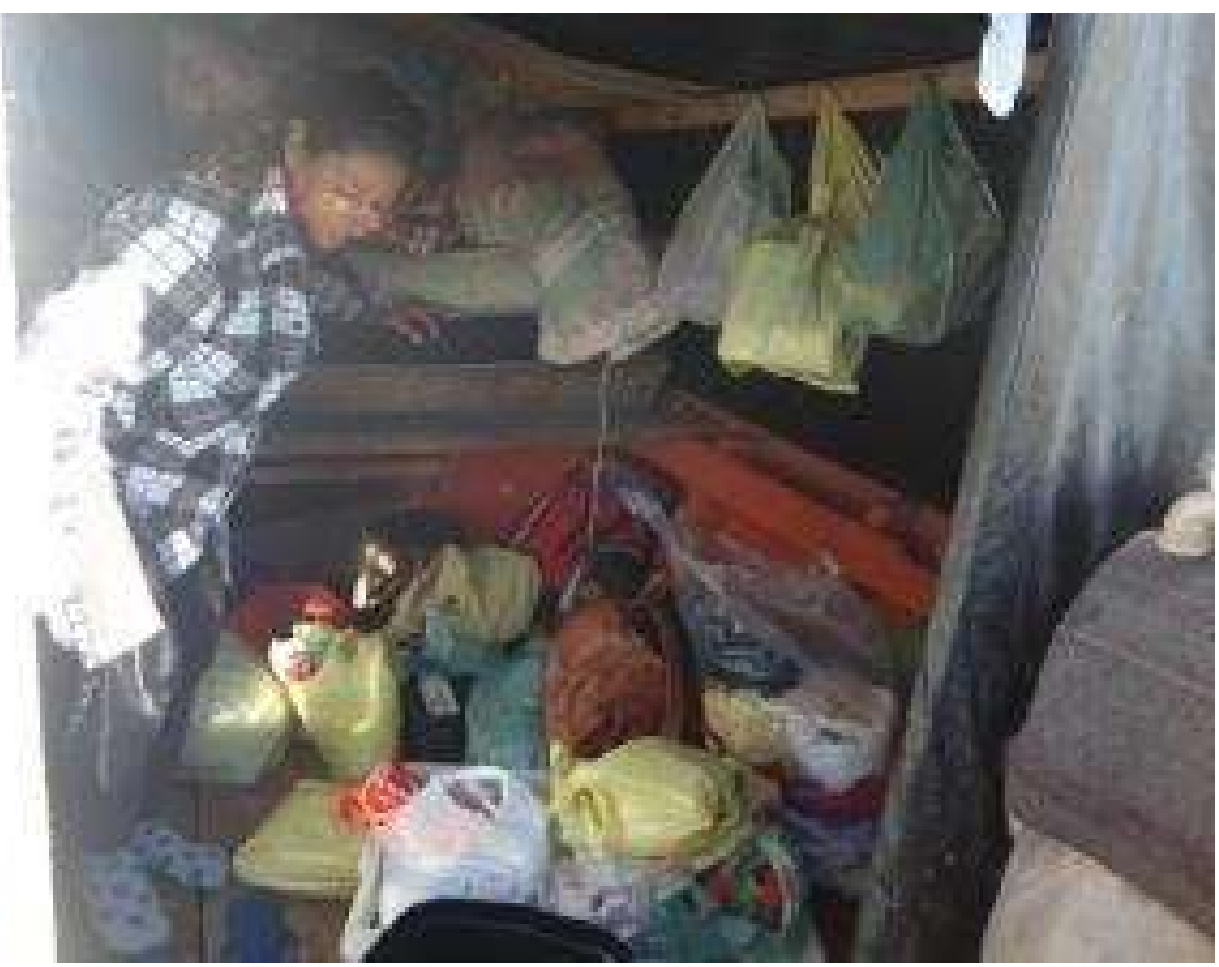

Figura 7 - Enquanto filho de Márcia assumia o leme, a pescadora arrumava os mantimentos, roupas e remédios no interior do barco

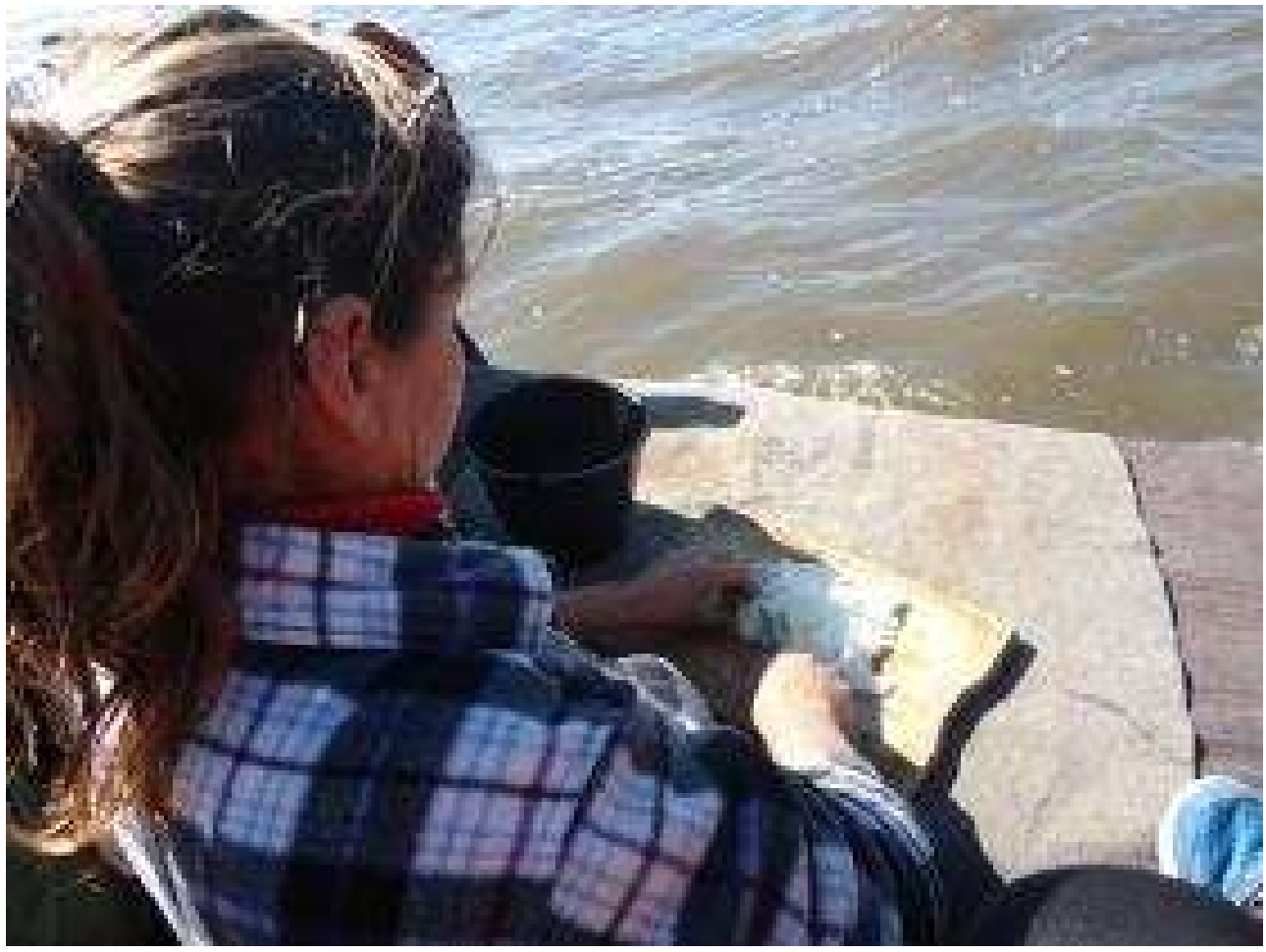

Figura 8 - Hora de cozinhar 


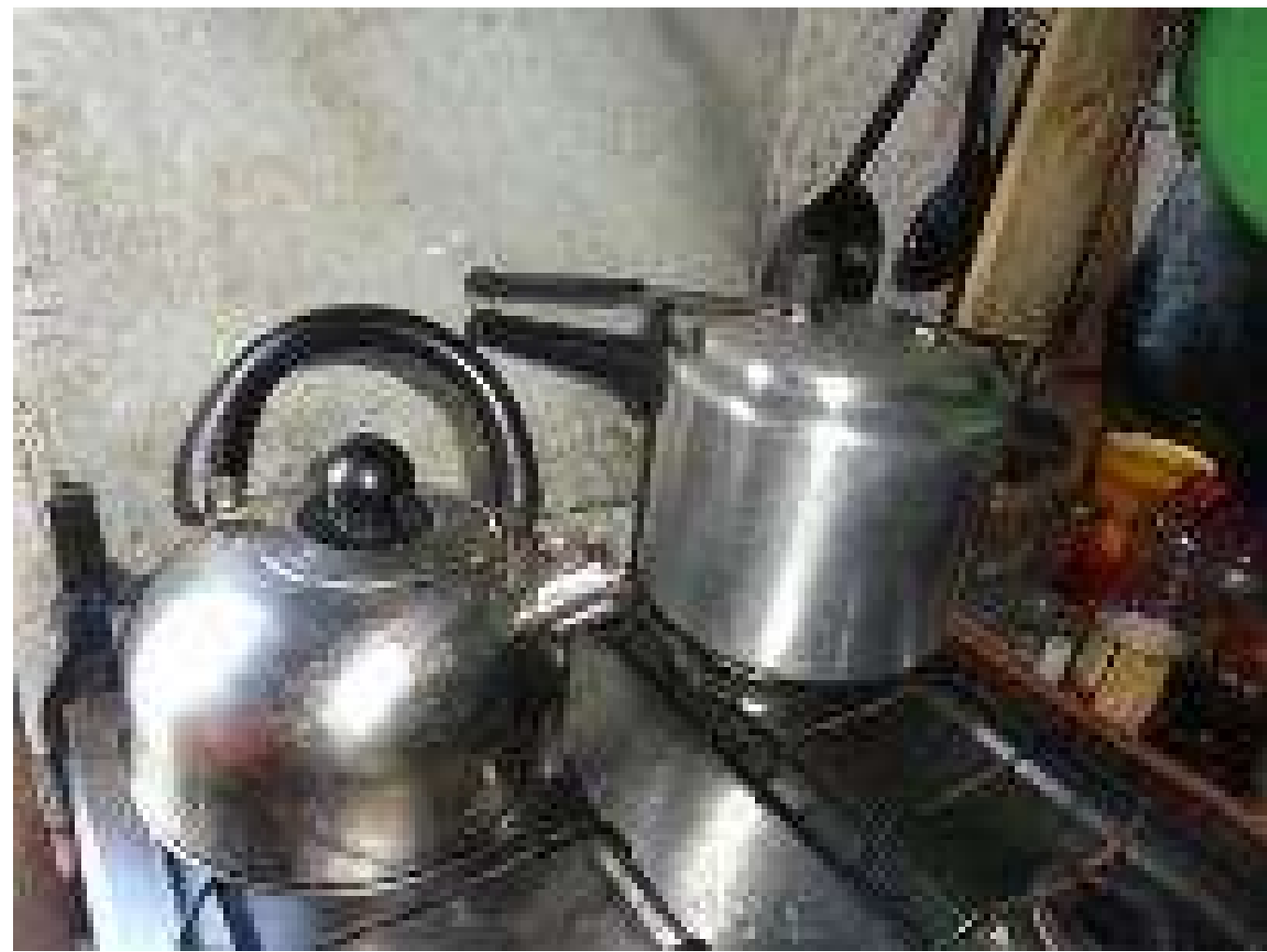

Figura 9 - Preparando o feijão no interior da embarcação

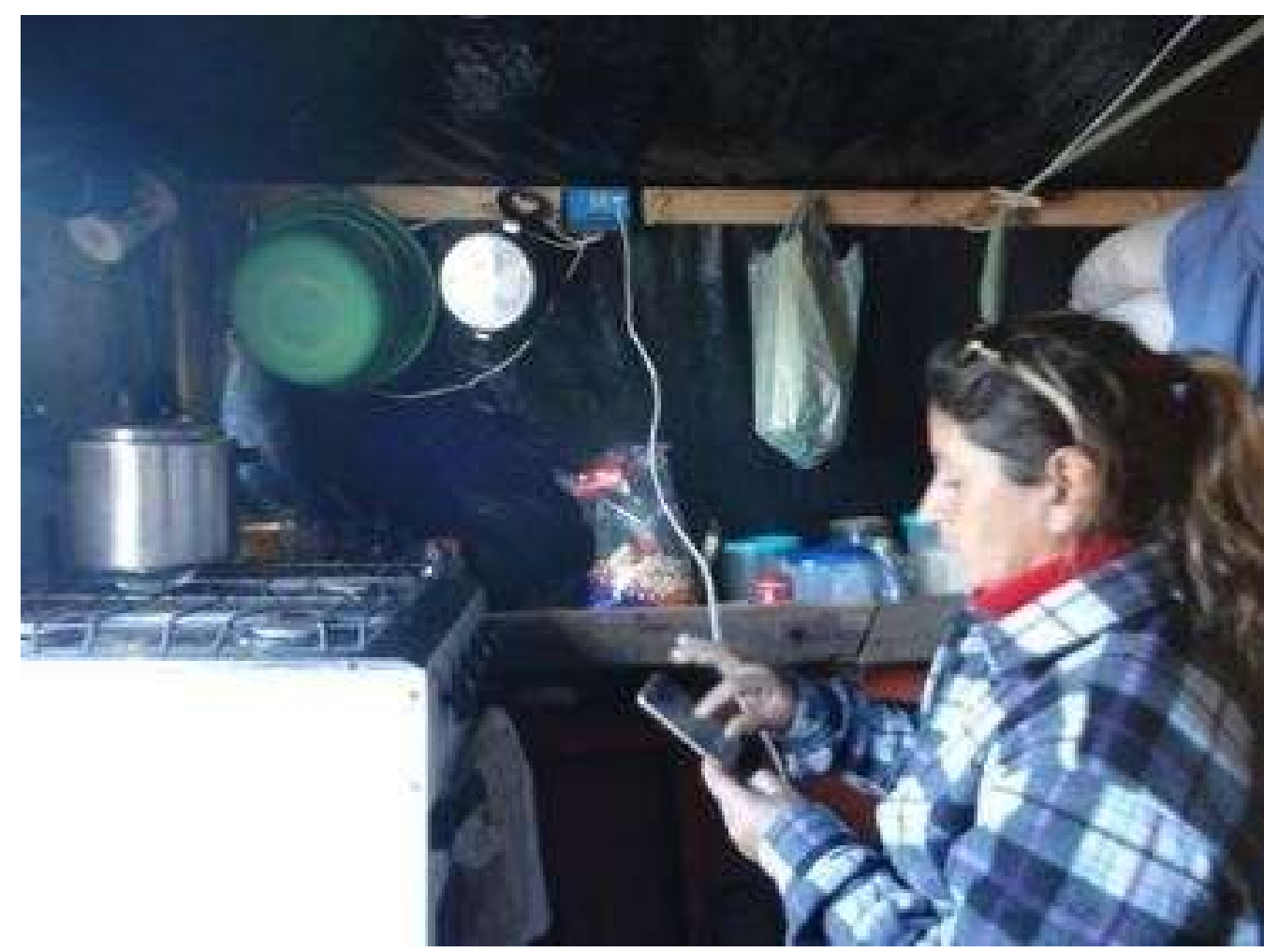

Figura 10 - Hora de localizar a nossa posição

Enquanto o filho de Márcia assumia o leme, ela organizava o barco e cozinhava o almoço. Cozinhou feijão e preparou um macarrão. De tempo em tempo ela saía do casario (estrutura de 
madeira coberta com lona preta onde ficam a cozinha, camas, roupas, alimentos) e com a mão posicionada acima dos olhos observava o caminho, as condições da lagoa e o tráfego de embarcações. Após a observação atenta, voltava para o casario e através do GPS no celular verificava a posição que estávamos e as condições do vento.

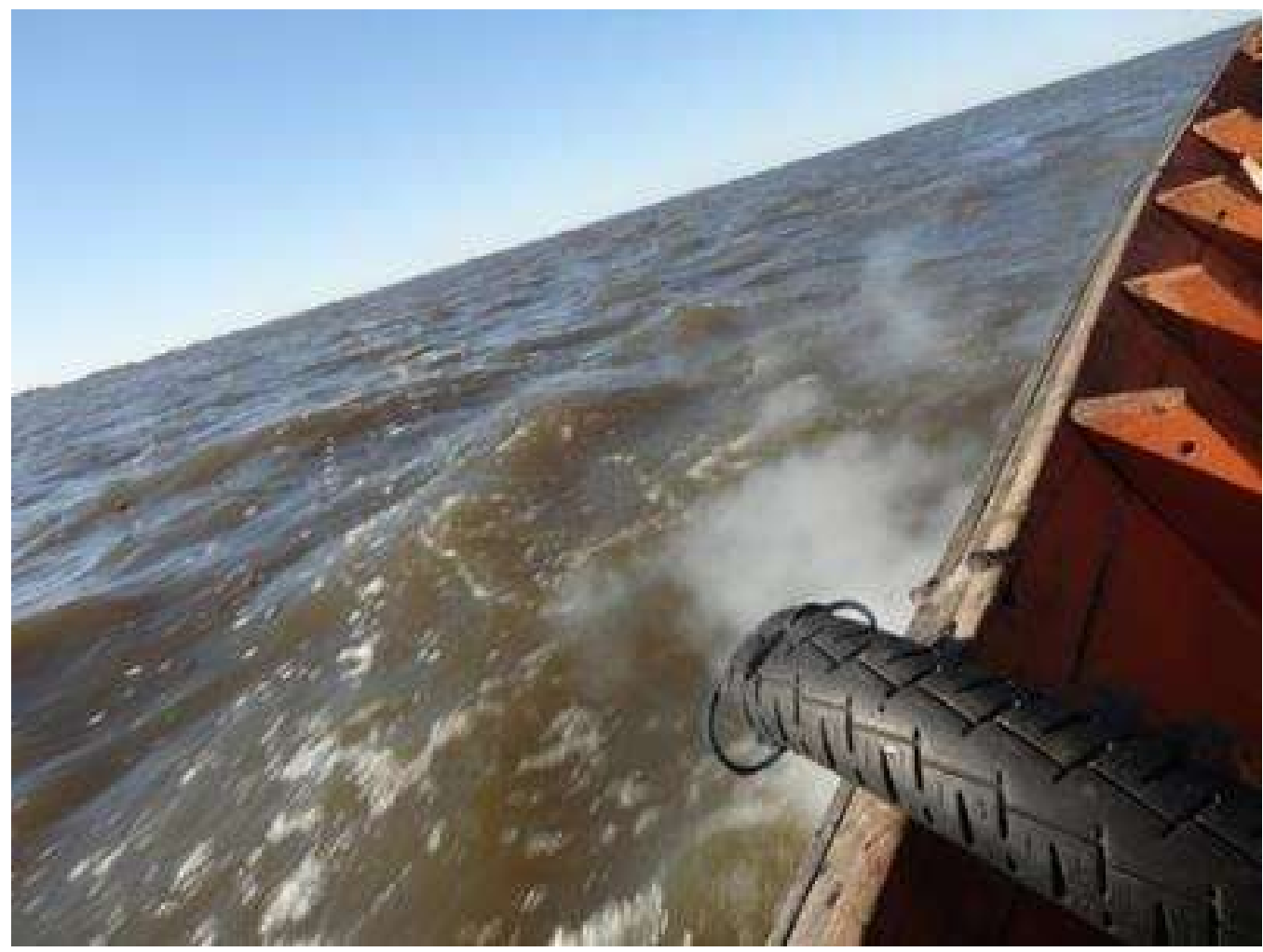

Figura 11 - motor, ondas e vento

Estávamos indo em direção a localidade Pontal de Canoa onde fica o acampamento de pesca da família de Márcia. Acampamento? Como seria se não estávamos levando barraca? Fiquei tentando imaginar esse cenário, mas somente tive a real consciência do que seria o tal "acampamento" quando chegamos finalmente no local. Navegamos por cinco horas ao som do motor, das ondas e do vento que nos acompanhavam. 


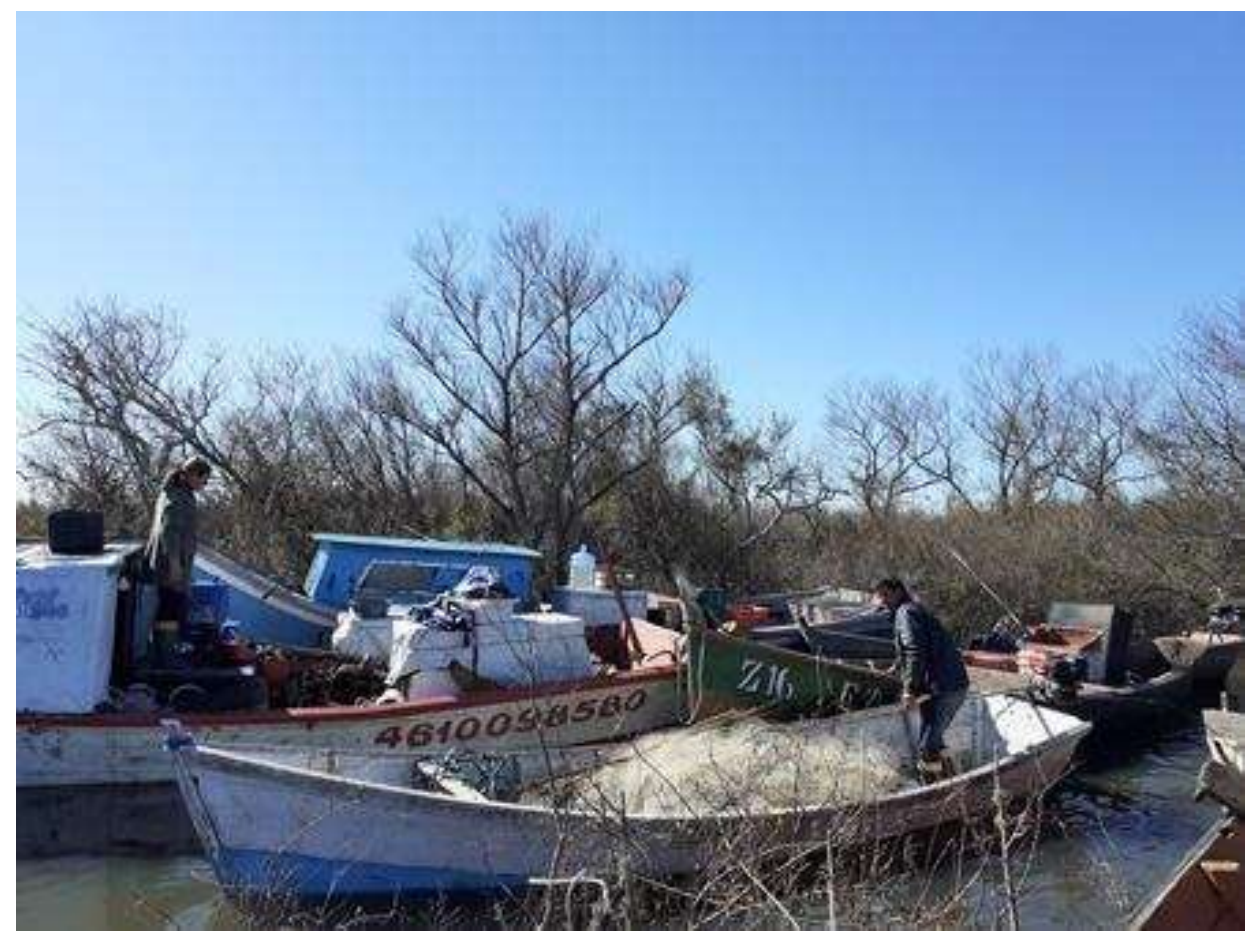

Figura 12 - imagem do acampamento

Figura 13 - O acampamento

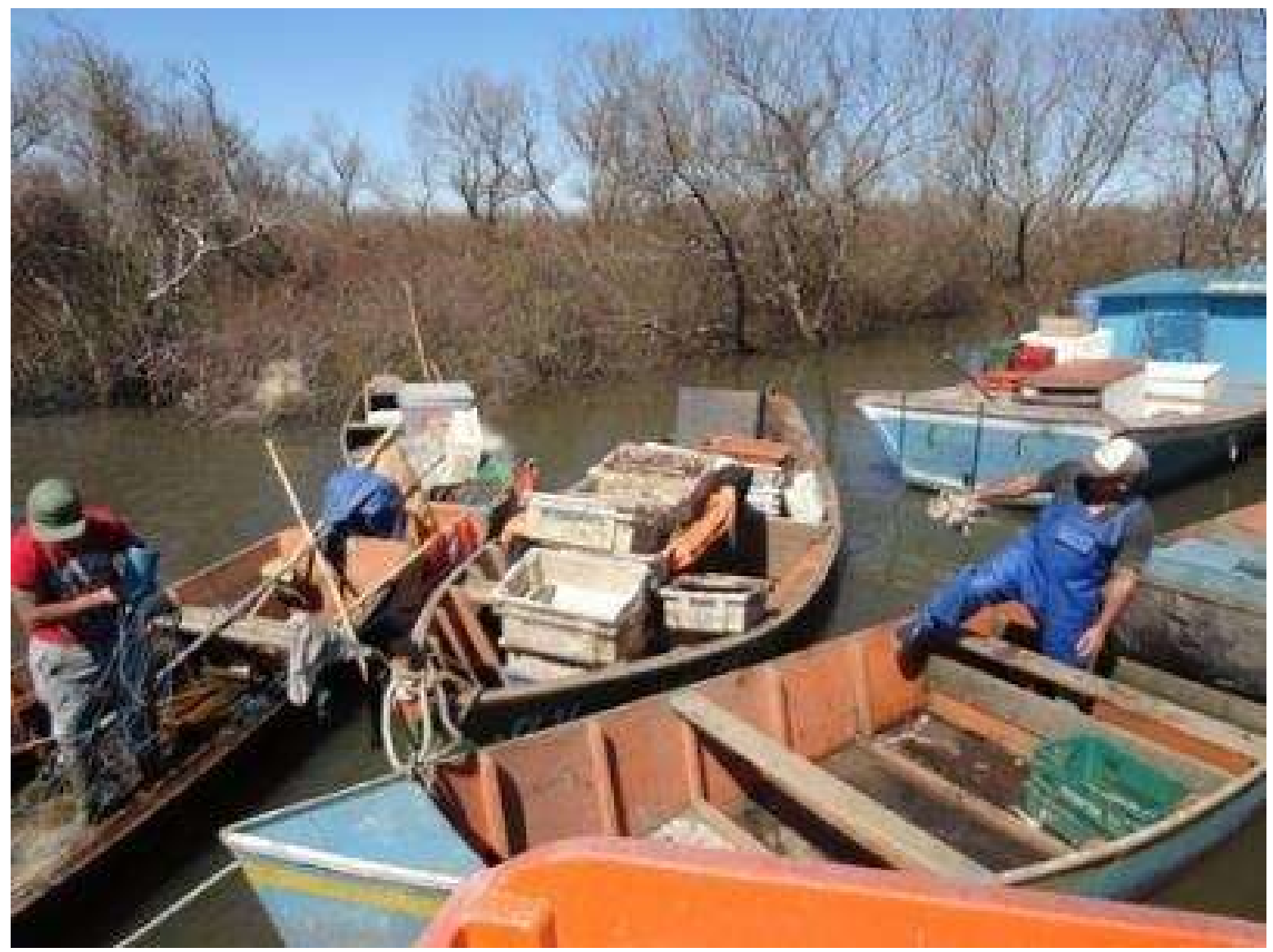


Chegamos às treze horas na localidade Pontal de Canoa e onde estava o acampamento. 0 filho mais velho de Márcia e a esposa estavam nos esperando. A paisagem se apresentava (conforme as figuras 12 e 13) com barcos grandes semelhantes ao que estávamos (de madeira, a motor, medindo cerca de 10 metros) e quatro caícos (barcos menores de 3 a 5 metros, também de madeira e a motor). Havia uma vegetação de sarandi que contornava a costa da lagoa. Naquele instante entendi que o acampamento se daria nos barcos, dormiríamos nas embarcações ancoradas.

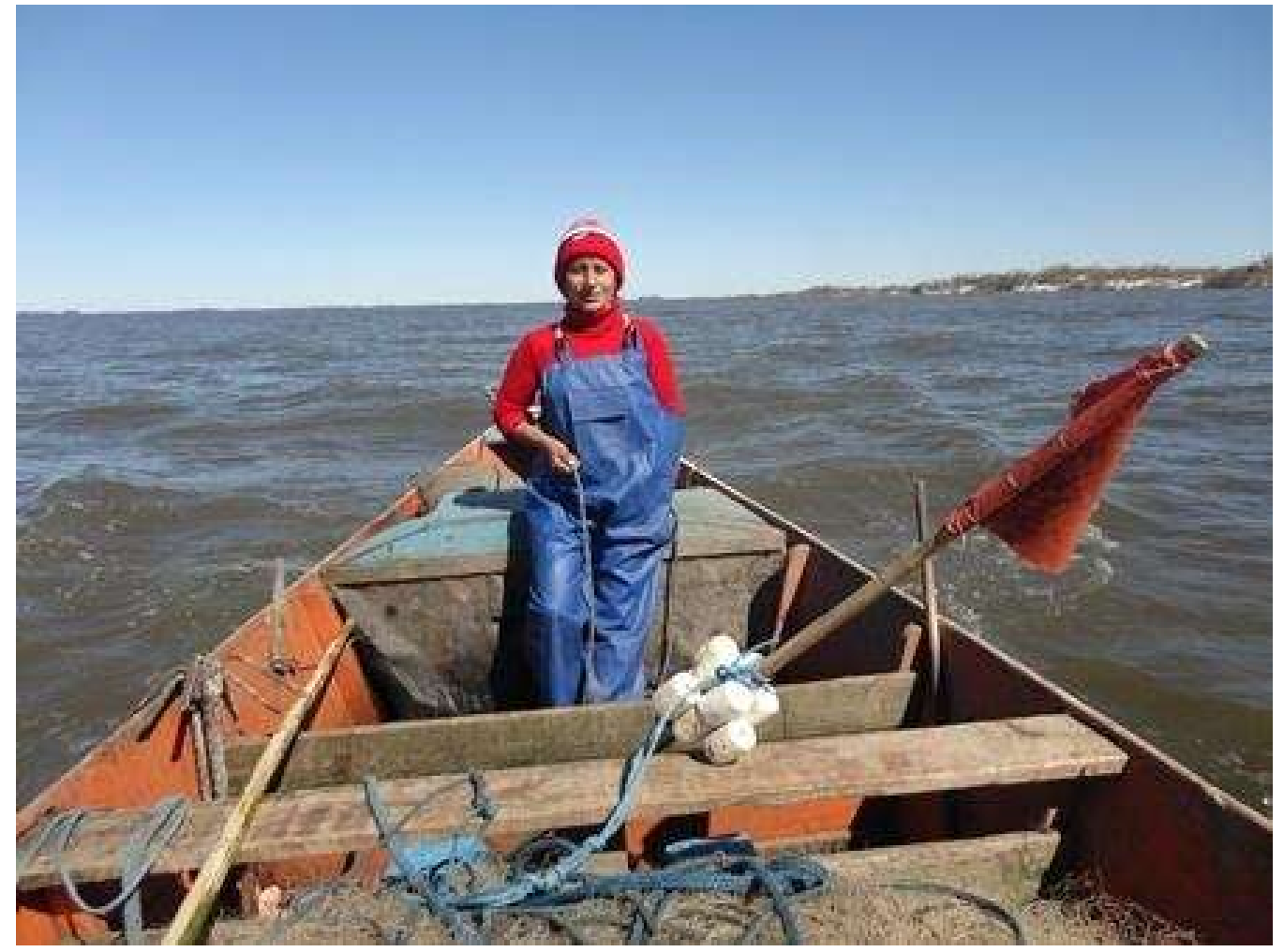

Figura 14 - Hora do trabalho de lançar e puxar redes.

Sem delongas Márcia olhou para mim e disse: vou puxar as redes que estão na água e colocar outras, vais comigo? Sem pestanejar, balancei a cabeça de cima para baixo, indicando um "sim". Ela sorriu e me alcançou o macacão de olhado. Ficamos parecidas. Aquela realidade estava me penetrando. Márcia ligou o motor e partimos na direção sul.

Alicerçada nas epistemologias ecológicas (Steil \& Carvalho, 2014; Ingold, 2015) as quais, a partir da compreensão e percepção, reivindicam a materialidade e autonomia do mundo se contrapondo à perspectiva representacional, libertando o conhecimento da mente humana $\mathrm{e}$ centrando na ação, propus abrir para análise novos domínios de conhecimento, tais como a vida, os sentimentos, os desejos, os corpos, as coisas, os seres, os fluxos, influxos e movimentos, centrada em como a pescadora faz no percurso da vida.

Entendo que isso é possível de ser realizado seguindo a mesma, penetrando e me deixando atravessar, percebendo e acompanhando os processos de aprendizagens constantes e dinâmicos nos emaranhados da vida social, cultural e política.

Na complexidade de uma realidade, a Márcia, e agora eu, estávamos sendo atravessadas pelas condições sociais, culturais e atmosféricas. Pelas marés, ventos, seres marinhos, estrelas, luas, pássaros, assim como pelas normativas da pesca, pelos homens e pelos conflitos 
socioambientais. Percebia ali de forma muito evidente que as dicotomias que marcam a ordem colonial/moderna/patriarcal se esvaem. Não há nenhuma possiblidade de separação.

Macacão de olhado, botas de borracha, barco, rede, ancora e bóias. Partimos para a experiência.

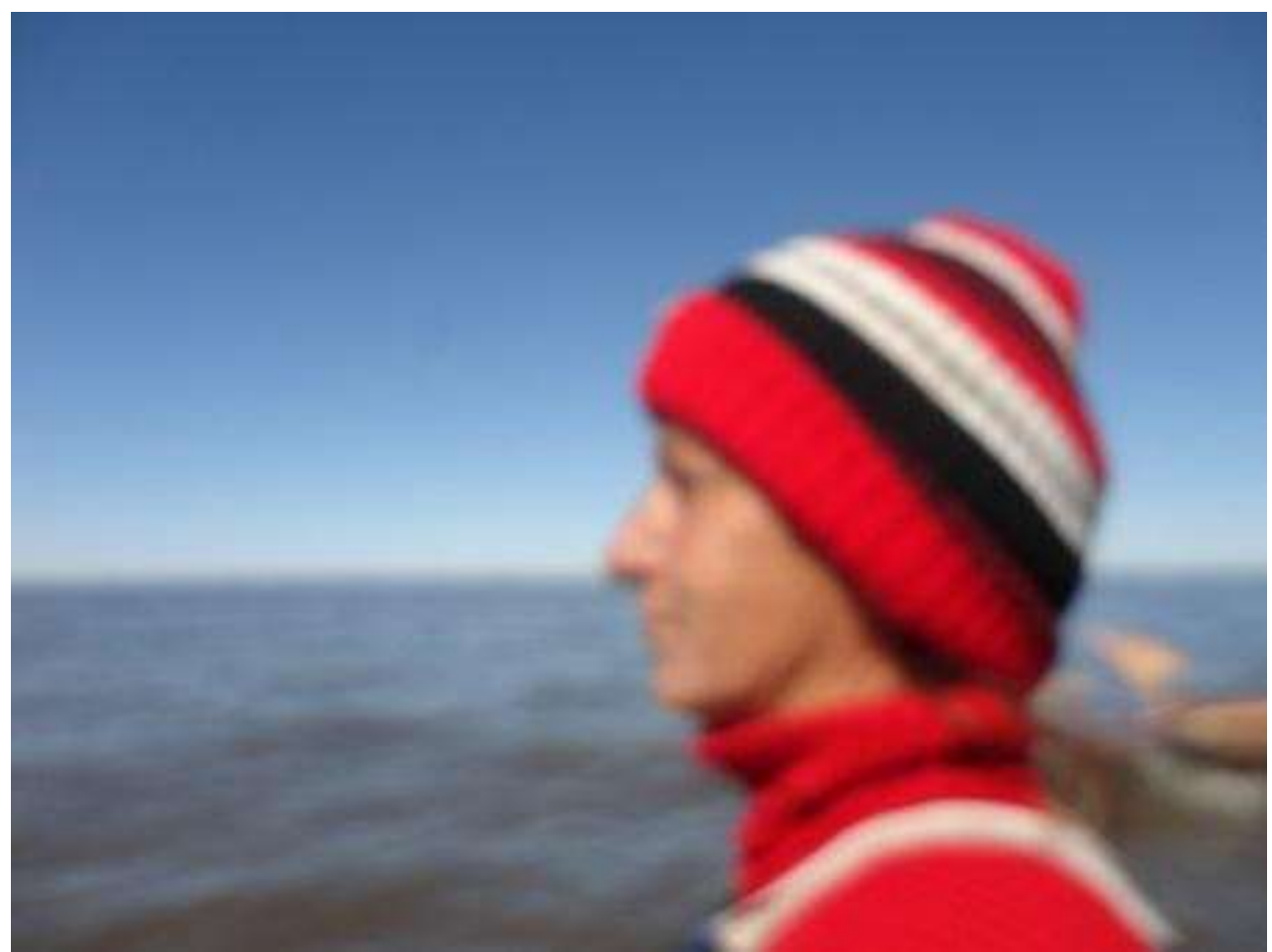

Figura 15 - visão da pesquisadora, aos poucos ajustando o foco

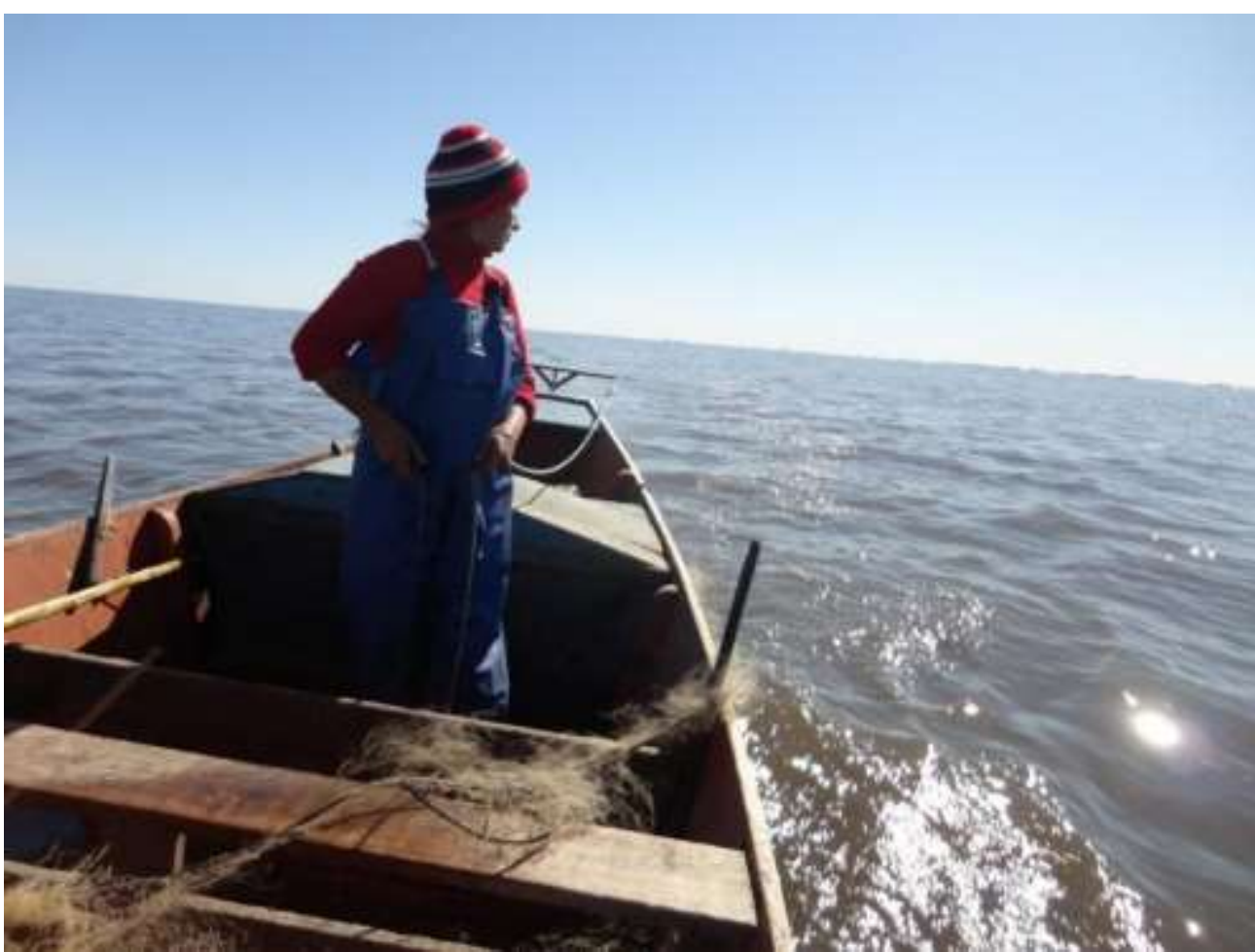

Figura 16 - O lançar da rede 


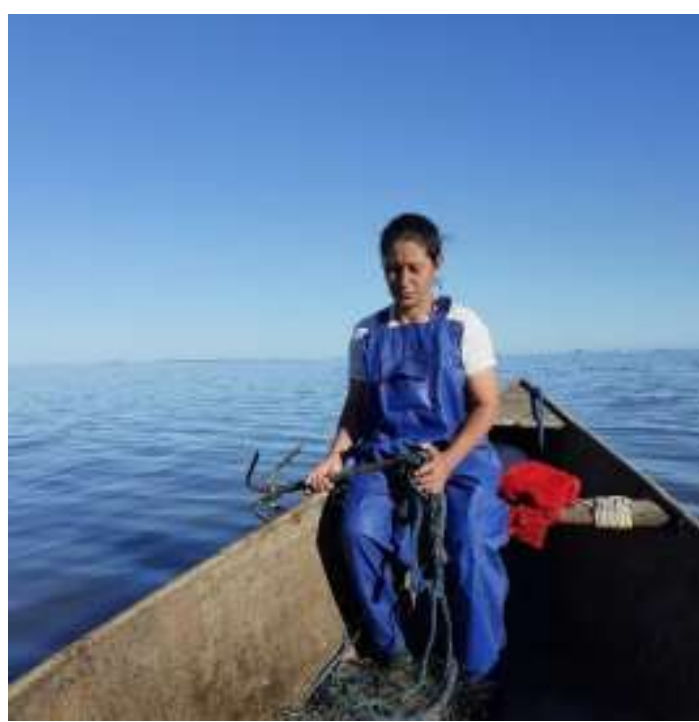

Figura 17 - Atirar a âncora

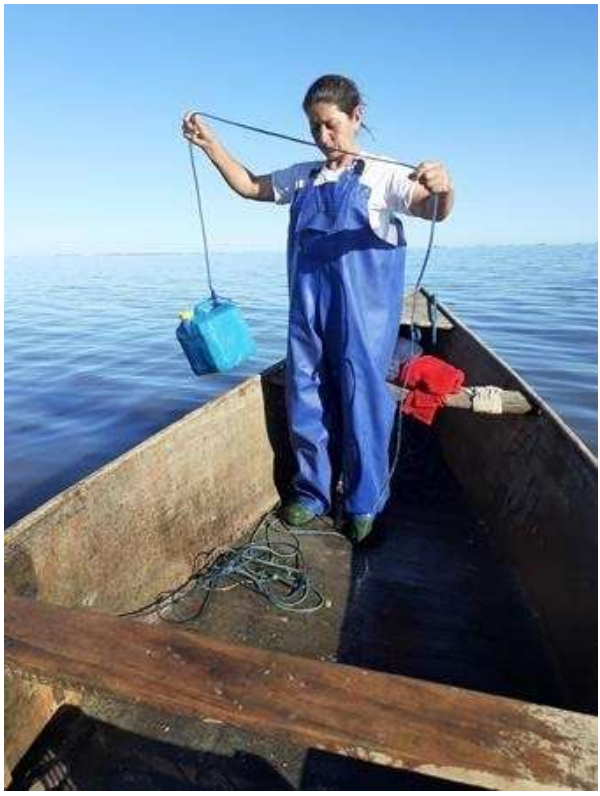

Figura 18 lançar a bóia

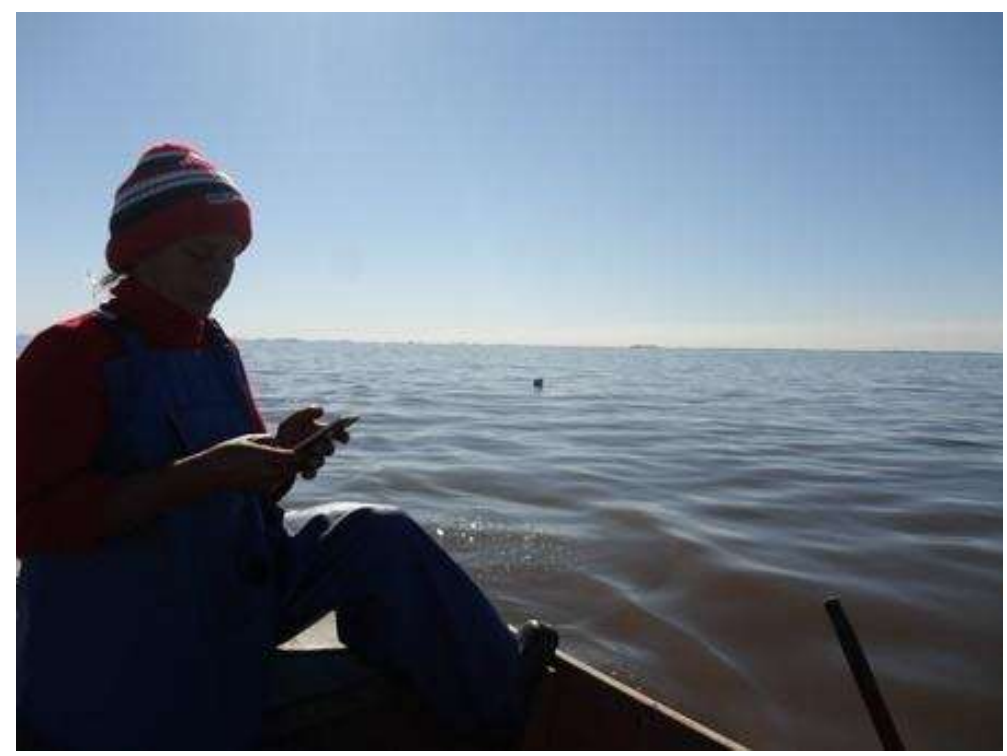

Figura 19 - - Bóia marcada no GPS

Minha visão ainda era turva. Nesse momento pouco entendia o que estava acontecendo. Ela, enquanto manejava o barco, olhava atentamente a lagoa como se estivesse procurando algo, em seguida disse: será aqui que lançaremos as redes. Curiosa, perguntei sobre o porquê do local escolhido e a explicação foi de que com base nas redes que colocaram em dias anteriores os peixes estariam ali.

Nesse momento compreendi que o engajamento da Márcia nesse ambiente lagunar é pleno e de acordo com Ingold (2015), conhecer é fundamentalmente uma habilidade que 
adquirimos na relação com os outros organismos e seres que habitam o mesmo mundo e não uma prerrogativa humana que se processaria no espaço restrito da mente como uma operação racional. Há, portanto, um saber com base na experiência com todos os elementos, que faz com que se possa enxergar por baixo e por cima da água.

Márcia lançou a rede, jogou a âncora e a bóia (a qual servirá de marcador para saberem onde colocaram a rede) e, por fim, marcou no GPS do celular a localização.

Lançamos as redes para a captura da Viola, espécie da família dos Cascudos Loricariidae, peixe de água doce que habita o fundo da lagoa. Ajudei no que podia, tentando ao máximo não atrapalhar, mas ao mesmo tempo me fazer útil. As coisas começavam a fazer sentido, pelo menos mais sentido do que quando chegamos.

Senti que estava conversando com aquela realidade. Seguindo os passos da pescadora, as vozes, os olhares, os movimentos, as ondas, os ventos, os peixes, as estrelas, porque foi assim que ela aprendeu com seu pai, mãe, avô e avó e também, sobretudo, com seus filhos, eis que a cultura e a vida são dinâmicas e em constante movimento de aprendizagens (Lave, 2015).

Movimento esse que subverte a ordem do patriarcado e da perspectiva categorial onde se pensa que a pesca embarcada de captura é atividade exclusivamente masculina. Mas não é não! Mulher pesca, navega e se arrisca, é dona de sua embarcação e de sua vida, tem força e coragem e, segundo Márcia, a pesca é para qualquer uma, basta querer.

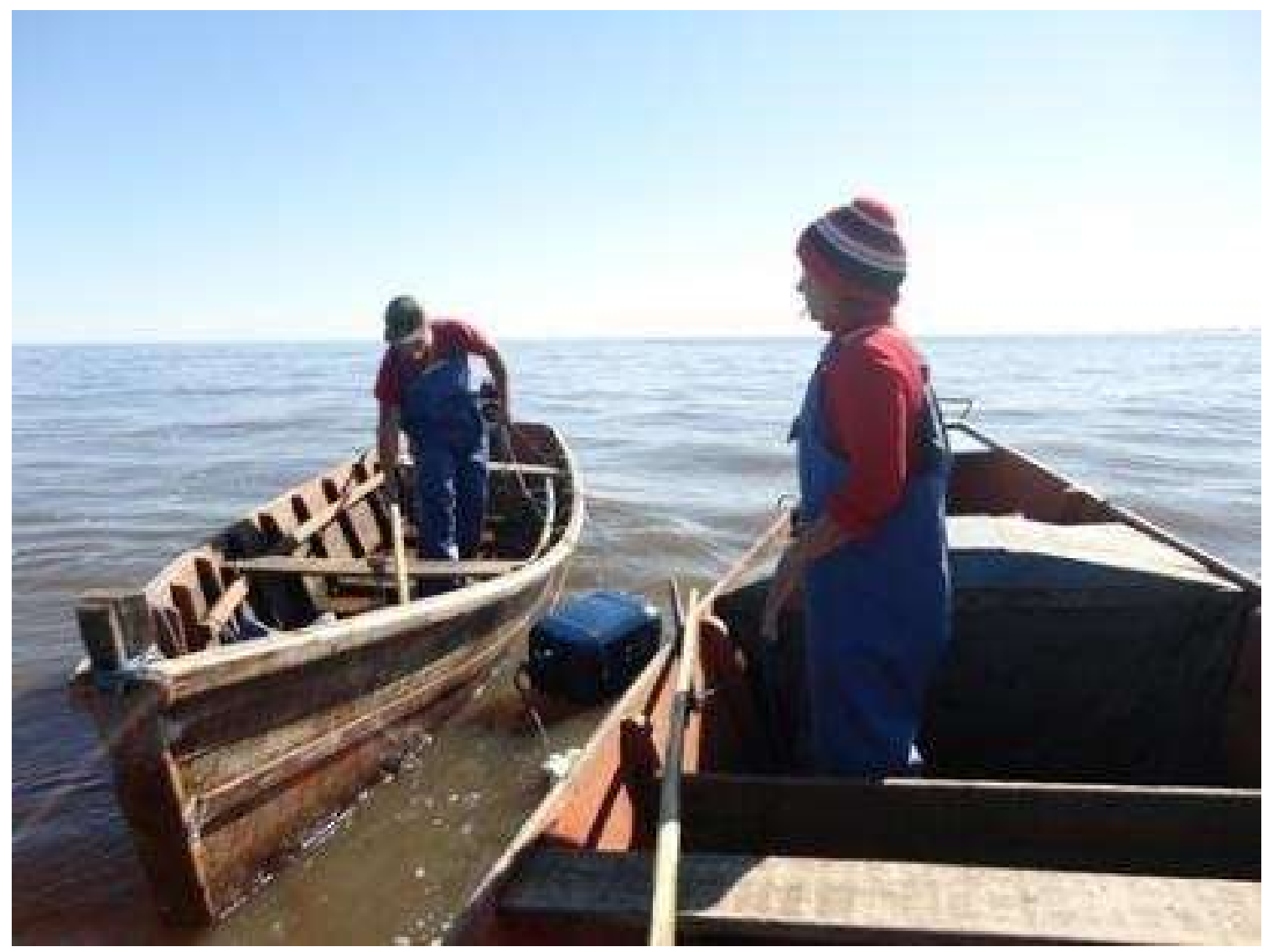

Figura 20 - - O filho que chega para ajudar a puxar a rede 


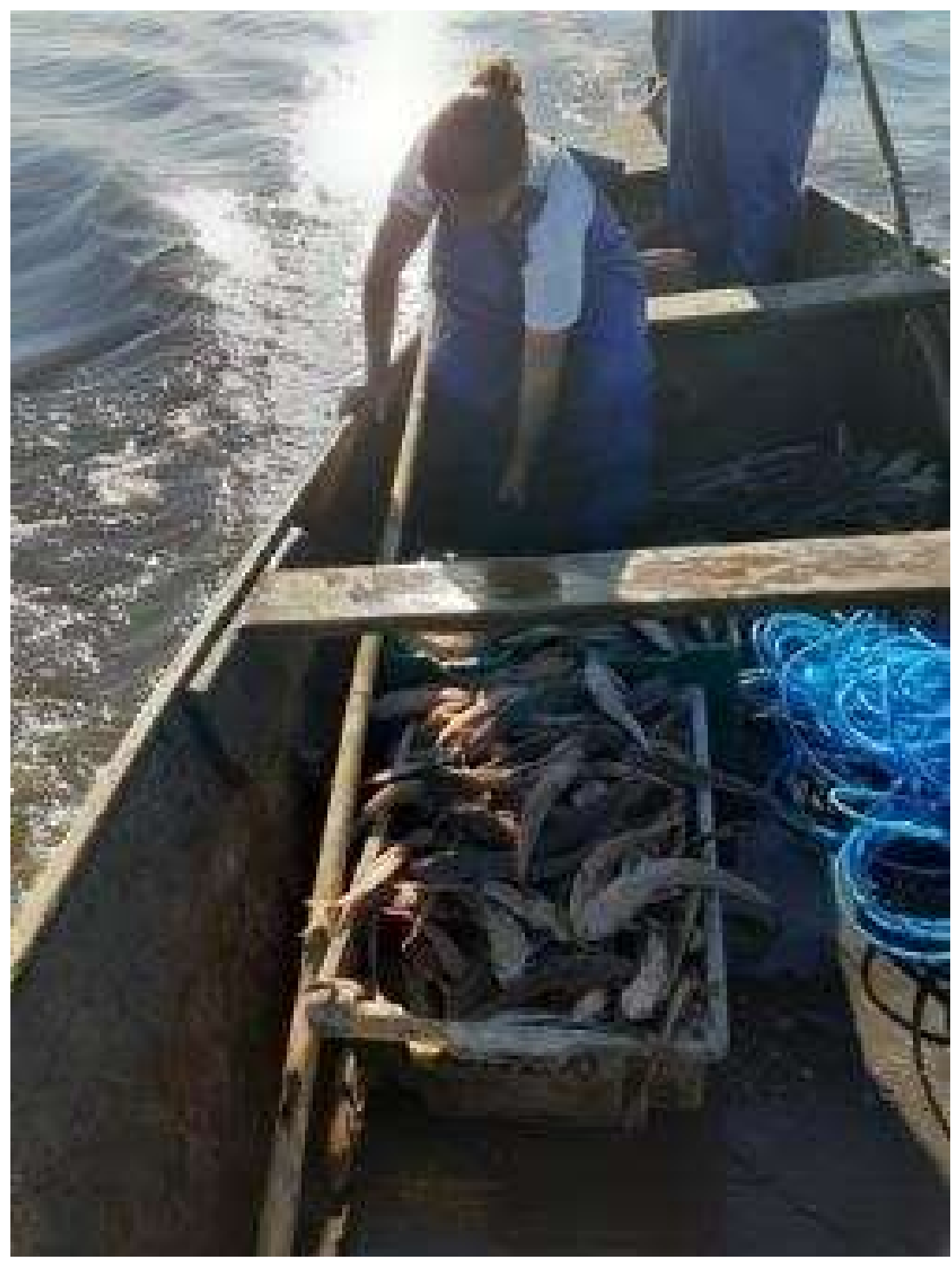

Figura 21 - Acondicionamento do pescado

Depois que lançamos as redes, navegamos uns metros e localizamos uma bóia. Nos aproximamos para verificar se era a bóia que o filho de Márcia havia colocado em dias anteriores. Márcia desligou o motor. Nesse momento, o filho mais novo se aproximou com seu caíco e começou a ajudar a mãe na puxada da rede.

Depois que puxaram os vinte metros de rede carregada, Márcia começou a despescar o peixe da rede, tentei ajudar, mas requer muita técnica e acabei ficando com a tarefa de organizar os peixes nas caixas dentro do barco. 


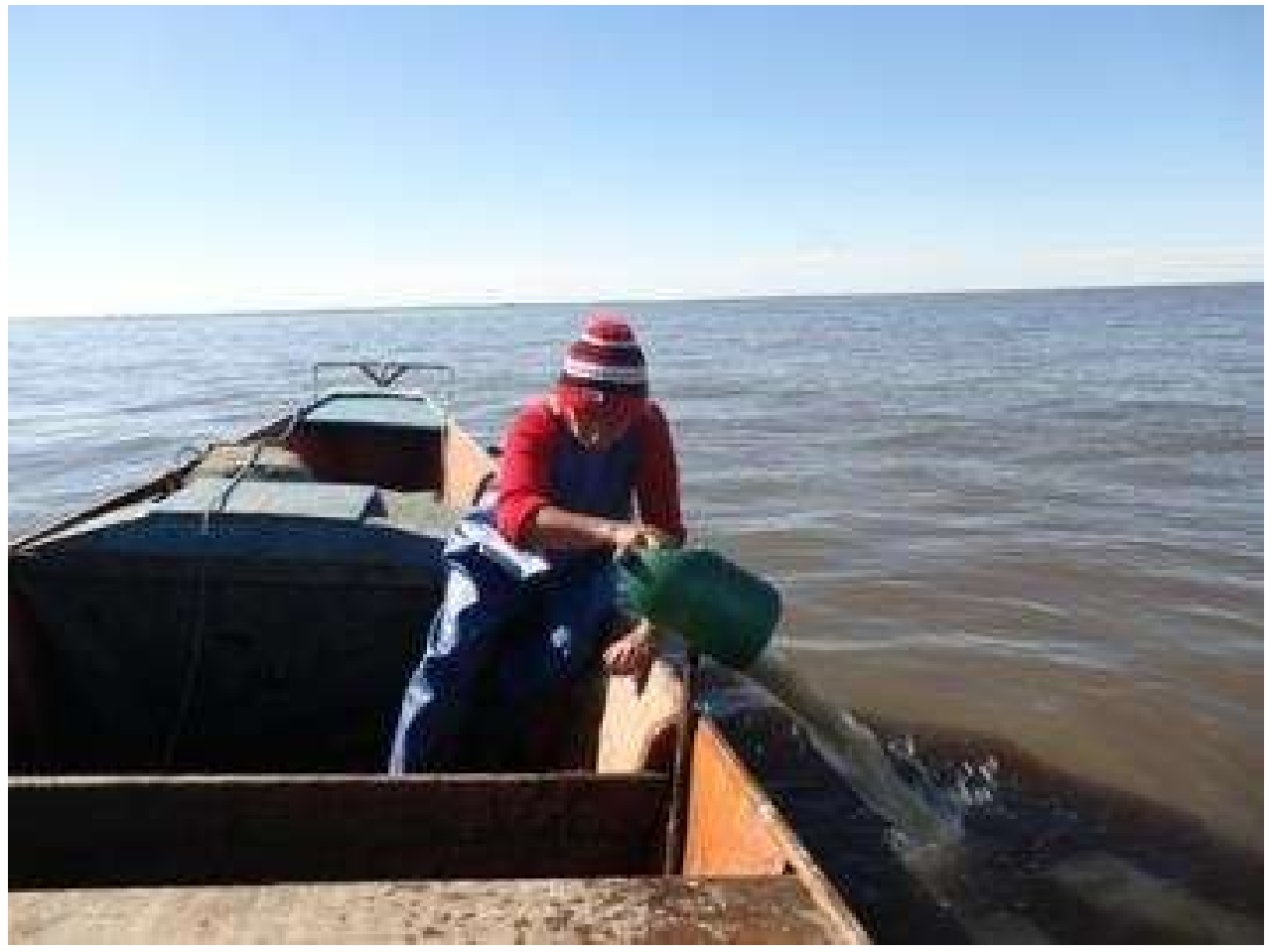

Figura 22 - Retirada da água

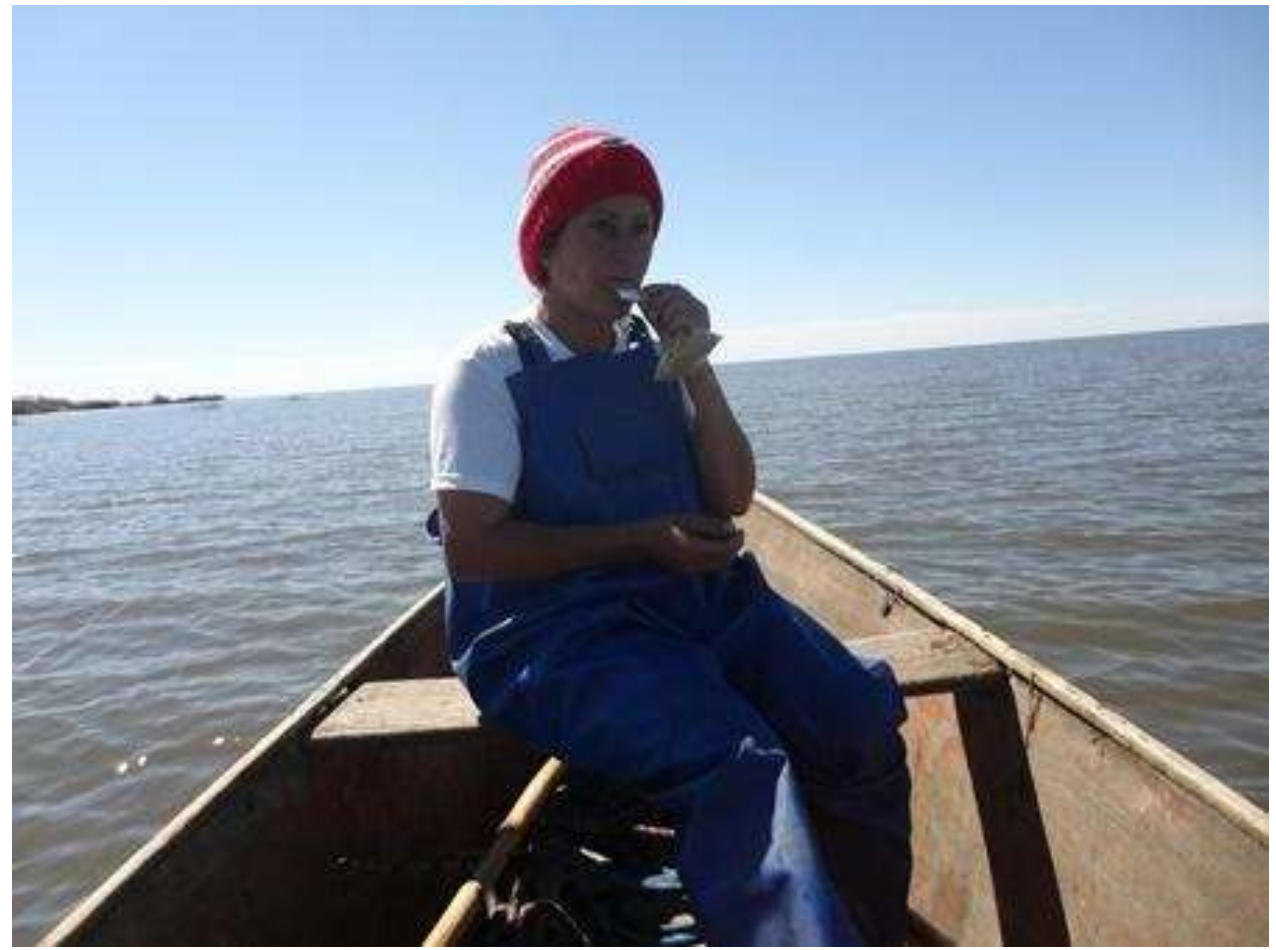

Figura 23 - Pausa para um cigarrinho, momento de reflexão.

Depois veio a hora da limpeza, retirada da água do barco e organização da embarcação. Nesse momento, mais descontraída e fumando seu cigarro, Márcia contou os conflitos que sofre na comunidade por estar pescando, já que é mulher solteira e isso traz de certa forma insegurança para as mulheres dos pescadores. Afirmou que não se preocupa pois faz o que 
gosta, já tentou se afastar da pesca, mas não conseguiu, vivia triste e não entendia o porquê, quando decidiu voltar para a atividade a alegria voltou. Disse que precisa estar em contato com a lagoa, viver essa vida que para ela se traduz em liberdade.

Ninguém me manda, fico aqui eu e a natureza, com os peixes eu me entendo, com a lagoa também. Me sinto livre. (Márcia)

Quando pensaríamos que uma mulher pesca por estar em busca da liberdade? Capturam peixes e liberdade? Mas porque estão atrás disso, se num primeiro olhar parece ser a pesca algo tão sofrido, expondo os corpos as intempéries que as fazem envelhecer rapidamente, com vento, chuva, sol, frio, ausência de peixes, normativas excludentes e desatualizadas?

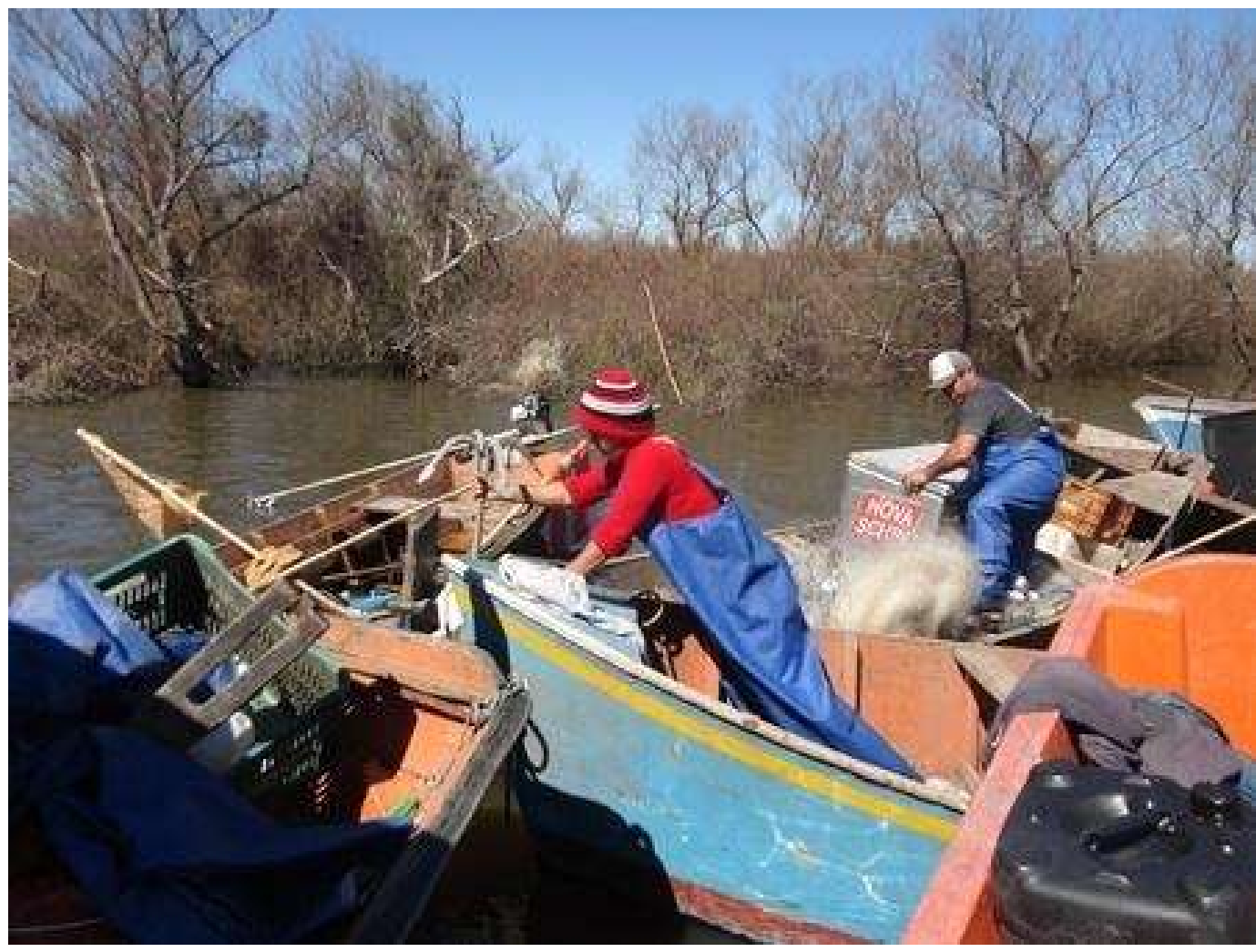

Figura 24 - A volta ao acampamento

A resposta vem da experiência. Ao experienciar a cultura da pesca, através da prática da pescadora embarcada, nos deparamos com as noções de pescar para ser livre, ou seja, não estar sob o jugo da dominação e de lutar constantemente à tudo que as oprime. Márcia se sente livre, uma vez que faz o que escolheu fazer e luta para estar e se manter ali.

Estar nas águas pescando e não em terra esperando, desencadeia a sensação de liberdade, livre da terra como lugar da opressão e da casa como lugar de dominação com tarefas determinadas para a mulher na sociedade patriarcal. Quando as pescadoras estão em terra, estão à espera da liberdade. À espera de ir para a lagoa encontrar esse lugar que requer ritmo e ação. 
Martins, L. y Adomilli, G. (2020) Tekoporá vol. 2, n² (167-187) DOI 10.36225/tekoporá.v2i2.52

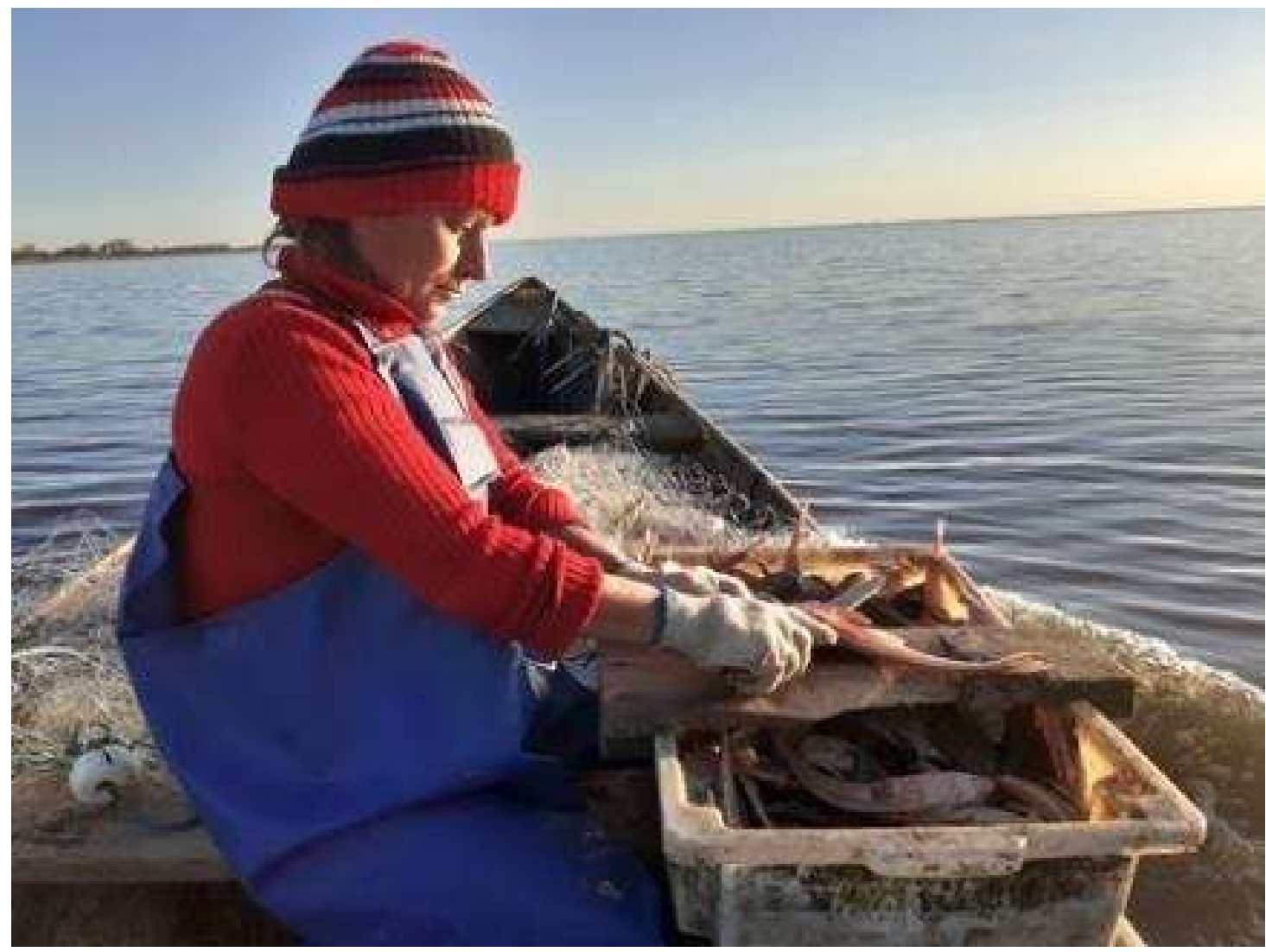

Figura 25 - Selecionando e limpando o peixe para a janta

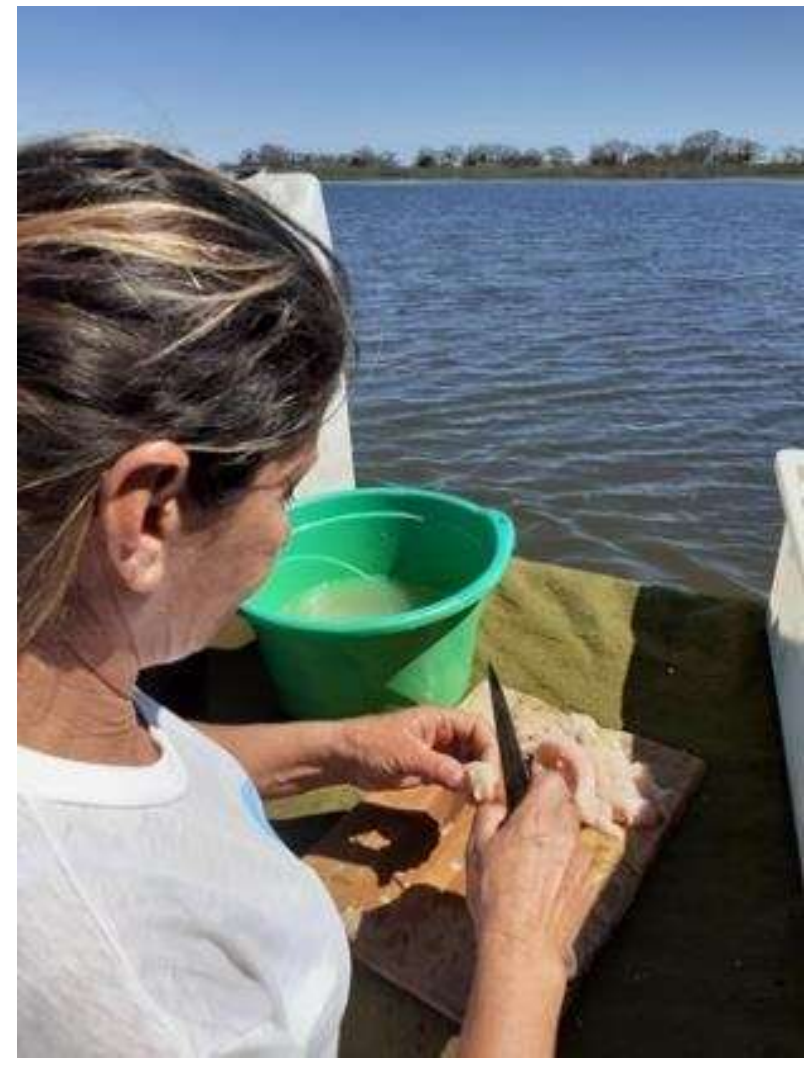

Figura 26 - Tirando o filé da Viola 


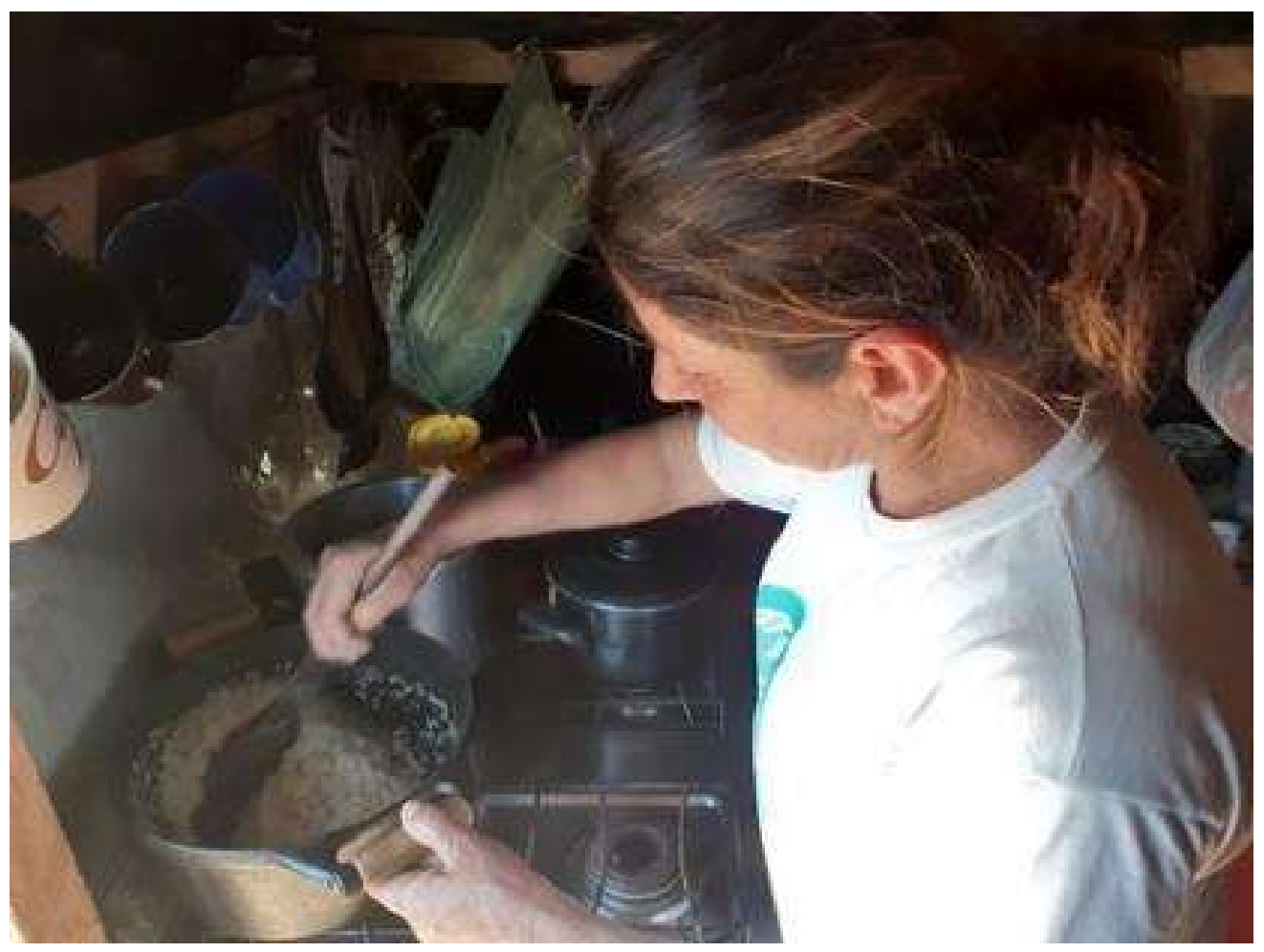

Figura 27 - Preparando o arroz.

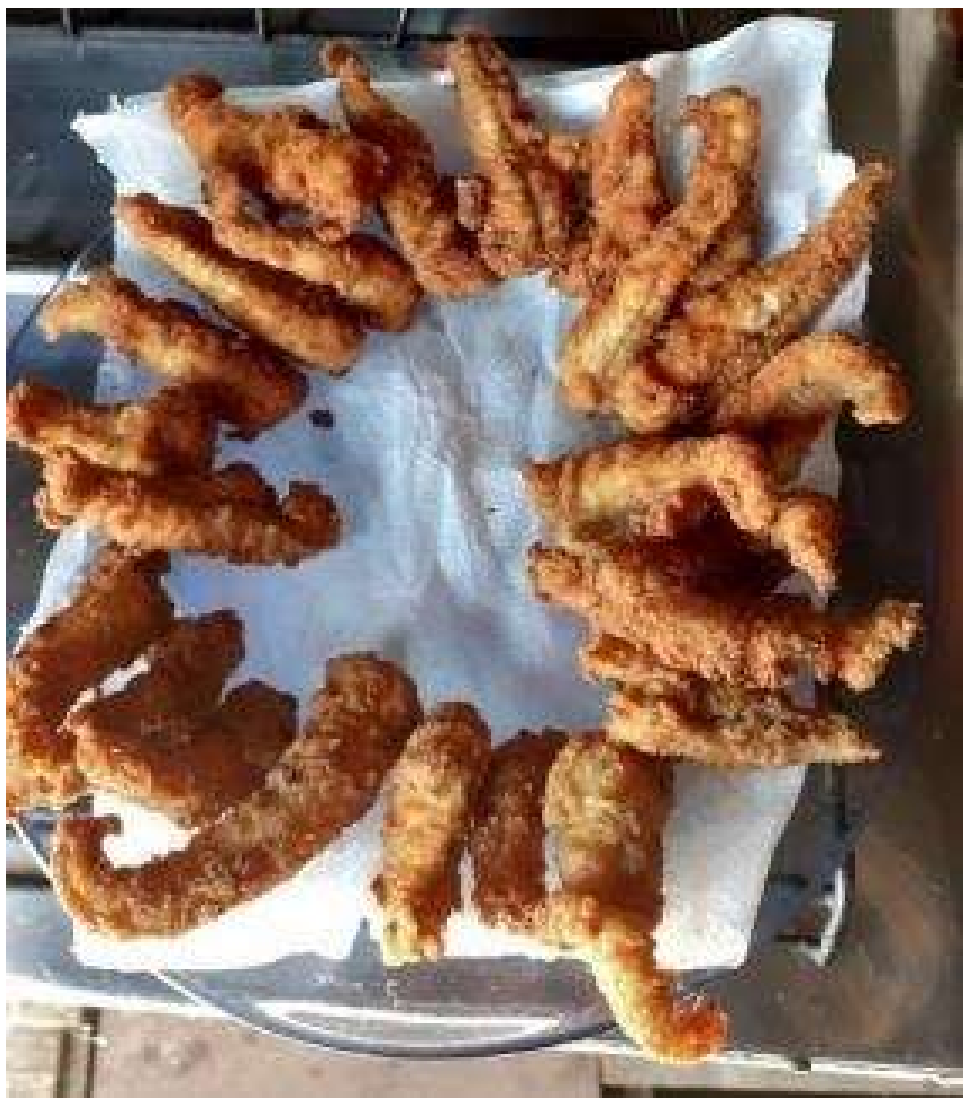




\section{Figura 28- A Viola frita}

Voltamos para a acampamento e lá a atividade continuou, agora em grupo com filhos, noras, irmã e cunhado que compõe o acampamento e a vida na pesca de Márcia. Se unem na organização dos caícos, na despescagem do peixe que alguns trouxeram malhados nas redes, na lavagem das mesmas e na separação do material de pesca. Márcia, enquanto se encarregava da limpeza do pescado para o preparo do jantar, explicou que o serviço é igual ao realizado em casa, cabe a ela cozinhar, limpar e organizar o barco. Tudo que se faz em casa se faz no barco, diz Márcia.

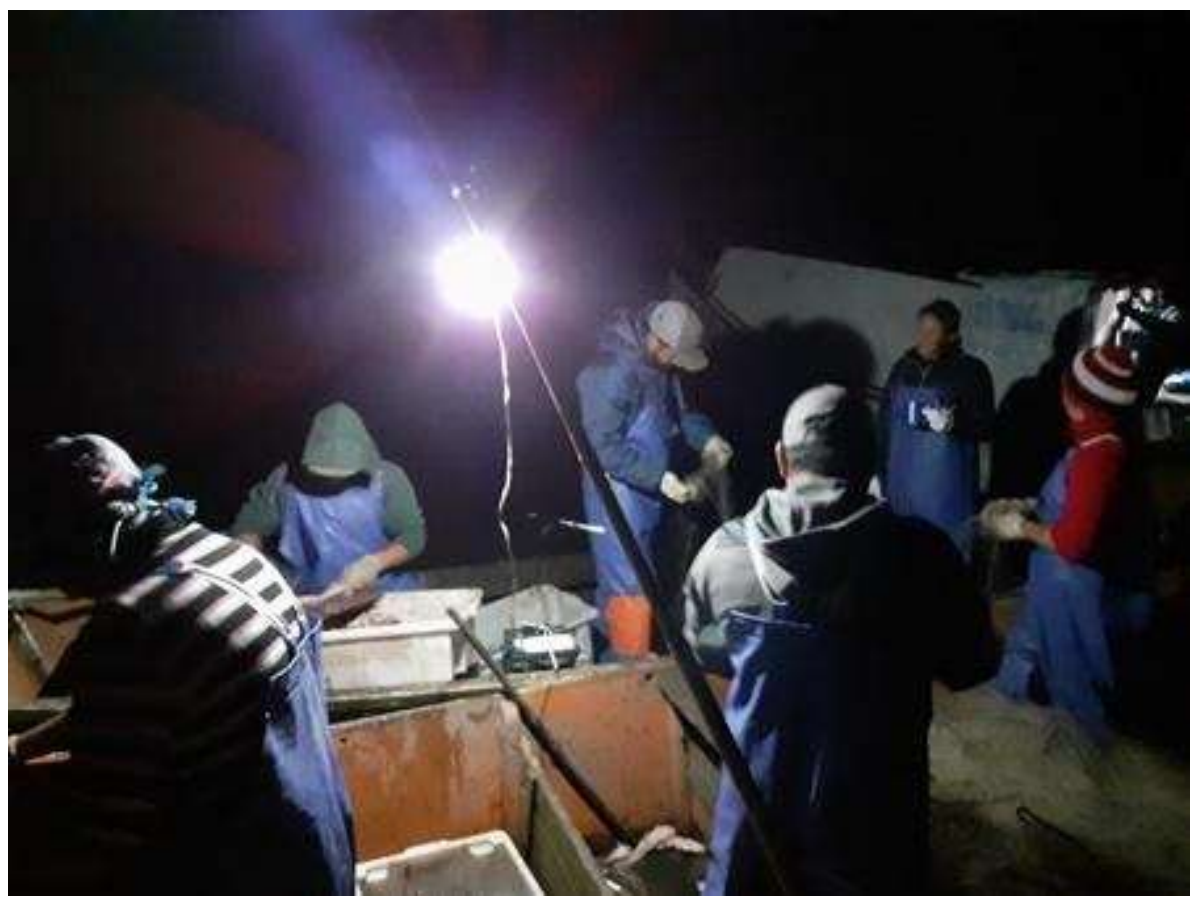

Figura 29 - Cai a noite, hora da finalização do trabalho, da conversa sobre o dia, planejamento sobre o amanhã.

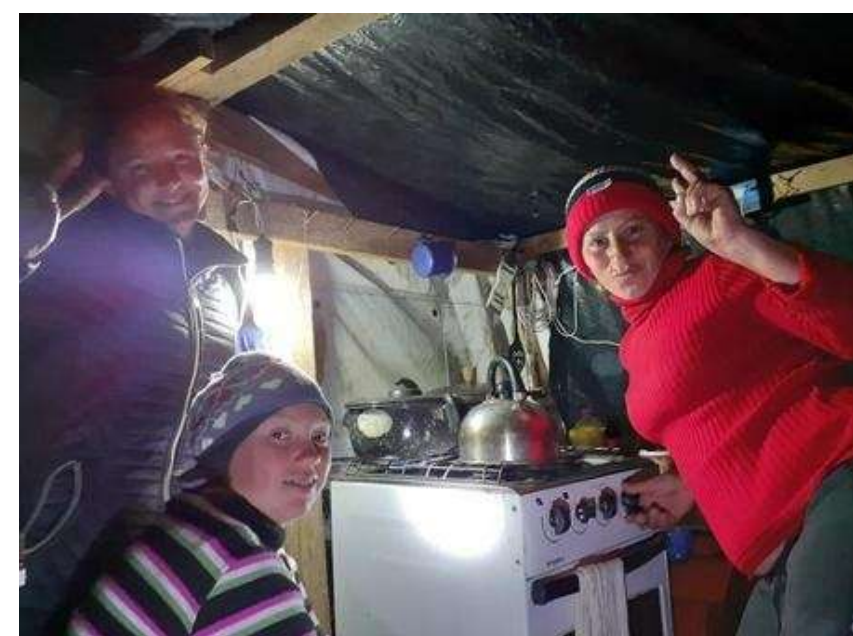

Figura 30 - Mulheres pescadoras, descontração e muita risada nos barcos-casas. 
A noite cai, as piadas e risadas divertem, o dia duro e o cansaço parece suavizar com a alegria e esperança de que no outro dia as redes trarão o dobro de peixes. Os filhos, nora, irmã e cunhado brincavam e despescavam o peixe, armazenavam no gelo o pescado e tomavam uns goles de cachaça para esquentar o corpo. Nesse momento de descontração aproveitaram e fizeram muitas perguntas direcionadas a mim.

Curiosos em saber o que afinal faz uma mulher nesse lugar? Porque os escolhi? Nesse momento expliquei sobre a pesquisa, sobre minha vontade de conhecer aquele modo de vida e sobre a metodologia etnográfica que, por sua vez, explicava o motivo de ter que acompanhar a Márcia na pesca. Márcia complementava dizendo estar feliz por ter alguém interessada nessa vida que ela leva na pesca.

Nesse momento destacaram minhas qualidades de neófita, o que revelava que passei na prova de fogo, no ritual de iniciação. Ela não enjoou, não teve medo, pode ir amanhã também falou o filho mais velho da pescadora, e, é claro, a risada rolou solta.

O espaço da cozinha era muito pequeno, mas todas nós cabíamos amontoadas no preparo para o jantar, éramos quatro mulheres. Auxiliei fazendo a salada de batata com maionese e a caipira de cachaça com suco artificial. Após o jantar as mulheres permaneceram conversando dentro do barco da Márcia e os homens na embarcação do filho mais velho.

O cansaço bateu, arrumamos as camas, cada um foi para sua embarcação e eu, Márcia e o filho mais novo ficamos no Náutico.

Ao experienciar a cultura da Márcia, a partir do encontro que o método etnográfico nos proporciona (Wagner, 2010), nos deparamos com a complexa rede que ela está envolvida, que ela tece e é ao mesmo tempo por ela é tecida, ou seja, que se constitui numa grande malha (Ingold, 2015) que trama todas as dimensões da vida com nós e emaranhados que se atravessam e dão outro sentido ou caminho.

Em cada trama, a criatividade e o poder de negociação surgem, e assim, o sentimento de liberdade é acionado por esta mulher fazendo resistir às adversidades de um mundo cujo pensamento está em crise, centrado no colapso planetário, no patriarcado e na perspectiva dicotômica e alienada.

Seguindo Escobar (2015) em sua análise sobre as lutas étnico-territoriais na América Latina, o autor nos ensina que ditas lutas constituem defesas de mundos e que os conhecimentos das comunidades incorporam uma proposta avançada contra a crise social e ecológica dos territórios.

Assim, segundo esse entendimento toda essa densa malha de inter-relações e materialidades existente na pesca embarcada praticada por uma mulher, nos diz que, não há pescadora, nem peixes, nem barco, nem motor, nem rede, nem maré, nem lua, nem lagoa como seres discretos, autocontidos, que existem por si mesmos, ou por sua própria vontade, o que há é um mundo inteiro que atua minuto a minuto, dia a dia, através de uma infinidade de práticas que vinculam uma multiplicidade de seres humanos e não-humanos na luta pela vida, e no caso da Márcia, além da luta pela vida, há a luta pelos direitos e liberdades das mulheres nesse Brasil de águas doces mas também muito salgadas. 


\section{Referências}

Adomilli, G. K. (2007). Terra e Mar, do viver e do trabalhar na pesca marítima: tempo, espaço e ambiente junto a pescadores de São Jose do Norte - RS. (Tese [Doutorado]). UFRGS. Porto Alegre.

Escobar, A. (2015). Territorios de diferencia: la ontología política de los "derechos al territorio". Cuadernos de Antropología Social 41, 25-38.

Gerber, R. M. (2015). Mulheres e o Mar. Pescadoras embarcadas no litoral de Santa Catarina sul do Brasil. Editora UFSC.

Ingold, T. (2015). Estar vivo: ensaios sobre movimento, conhecimento e descrição. São Paulo, Brasil: Vozes.

Lave, J. (2015). Aprendizagem como/na prática. Horizontes Antropológicos 21, (44), jul./dez, 37-47.

Piedras, S. R. N., Santos, J., Fernandes, J., Tavares, R., Souza, D. y Pouey, J. (2012). Caracterização da atividade pesqueira na Lagoa Mirim, Rio Grande do Sul, R. Bras. Agrociência, 18 (2-4), pp.107-116, abr-jun.

Steil, C. A. \& Carvalho, I. (2014). Epistemologias ecológicas: Delimitando um conceito. Mana 20 (1), 163-183.

Wagner, R. (2010). A invenção da cultura. São Paulo, Brasil: Cosac Naify. 